\title{
Distribution of the European bladdernut Staphylea pinnata (Staphyleaceae) in Poland
}

\author{
Łukasz Piechnik ${ }^{*}$, Przemysław Kurek² \& Tomasz Wójcik ${ }^{3}$
}

\section{Article info}

Received: 23 Mar. 2021

Revision received: 16 Jul. 2021

Accepted: 19 Jul. 2021

Published: 31 Dec. 2021

\section{Associate Editor}

Elżbieta Cieślak

\begin{abstract}
This paper presents the current distribution range of the protected shrub European bladdernut Staphylea pinnata in Poland. The study was based on a literature review, multidisciplinary search methods and field visits. The paper presents 211 sites considered as natural (including $48 \mathrm{new}$ ) and 143 sites considered as sites of anthropogenic origin (including 116 new). The data included in this paper extend the natural range of the species mainly in the Sudety Mts and Sudety Foreland, Rożnów Foothills, and the Tarnogród Plateau. It has been confirmed that the areas of Przemyśl Foothills (54 sites) and Dynów Foothills (49 sites) are the sites most abundant in bladdernut considered as natural. A few sites of anthropogenic origin have been found in the area of northern Poland, several hundred kilometres from the border of the bladdernut continual distribution range. In the case of sites of anthropogenic origin, knowledge of their distribution has increased significantly. This paper provides a basis for further research on the bladdernut in Poland and Europe and may be useful in population management of this protected species.
\end{abstract}

Key words: distribution, Poland, protected plant species, Staphylea pinnata

\section{Introduction}

European bladdernut Staphylea pinnata (hereinafter bladdernut) is the only native representative of the Staphyleaceae family in Central Europe. Considering its contemporary distribution range, the species is most abundant in Bulgaria, Romania, Moldova, Hungary, Austria and Croatia (Meusel et al. 1978). Westwards, its range extends to Italy, Switzerland, eastern France and Belgium (the Jura Mountains, the Vosges and the Ardennes). The northern border of the range consists of disconnected clusters in southern parts of Germany, Czechia (mostly in Moravia), Slovakia, western Ukraine and southern Poland. The species is also found in Armenia, Georgia, Azerbaijan and Russia (Krasnodar Krai), as well as in enclaves in Turkey, where its exact range is poorly known (Gostyńska 1961; Browicz 1986; Heiss et al. 2014).

Bladdernut was associated with the culture of several prehistoric and historic tribes (especially Celtic, Germanic and Slavic) (Hegi 1965; Heiss et al. 2014). Probably due to the spectacular shape and size of its flowers and fruits, this shrub was worshipped - it was used first in pre-Christian

\footnotetext{
${ }^{1}$ W. Szafer Institute of Botany, Polish Academy of Sciences, Lubicz 46, 31-512 Kraków, Poland

${ }^{2}$ Department of Plant Ecology and Environmental Protection, Adam Mickiewicz University, Uniwersytetu Poznańskiego 6, 61-614 Poznań, Poland

${ }^{3}$ Department of Nature Conservation and Landscape Ecology, University of Rzeszów, Zelwerowicza 4, 35-601 Rzeszów, Poland

* Corresponding author e-mail: 1.piechnik@botany.pl
}

and later in Christian religious rites. Shrubs were also planted on warrior tombs and near settlements (Hegi 1965). Currently, many sites are still situated on or near former settlements and hillfort ramparts (Towpasz 1987; Suder 2014; Piechnik unpubl. data). As bladdernut wood is very hard and resistant to abrasion, people used it for utility and religious purposes, to make crosses, sculptures, handles of tools, walking sticks and dashers for butter churns (Gostyńska \& Surmiński 1961). Jewelry, such as necklaces, earrings, bracelets and rosaries, were made from bladdernut seeds. The remains of such objects are found during archaeological excavations (Opravil 1962; Latałowa 1994; Rybníček et al. 1998; Heiss et al. 2014). The branches of bladdernut were traditionally used for Easter palms and bouquets for various religious celebrations. Some of these customs are still practiced in some regions of Central Europe (Gostyńska 1962; Łuczaj 2009). As a consequence of its multiple uses and ornamental value, bladdernut shrubs were often dug out of natural sites and planted near human settlements (Heiss et al. 2014). Along with the natural migrations of the populations related to climate change, seeds and perhaps young plants were often moved over considerable distances by people. As a result, there are now numerous anthropogenic (feral or backyard) sites of bladdernut (Boratyński \& Kwiatkowski 1998; Piechnik $\&$ Kurek 2020) (Fig. 2). The disappearance of some natural sites of this species is probably another consequence of digging up bushes from forests (Malik \& Nogawka 1999). 
The origin of bladdernut in Poland is not yet fully understood. The genus Staphylea appeared on Polish territory in the older Miocene and gave way with the Pleistocene glaciations (Środon 1992). The absence of paleobotanic material from the Quaternary - given the fact of finding seeds in early mediaeval archaeological material - indicates a relatively recent $(2,500-1,000$ years ago) return of bladdernut to the areas located to the north of the Western Carpathians (Klichowska 1956; Latałowa 1994; Heiss et al. 2014). We can suppose that this shrub naturally migrated to the areas of southern Poland by routes similar to other species of sub-Mediterranean flora (Kozłowska 1931; Cieślak 2014). However, the anthropogenic origin of at least part of the Polish population cannot be excluded. This could result from digging up, transplanting and trading in bladdernut shrubs in ancient and mediaeval times.

Bladdernut - due to its limited range, threats related to human activity (removal and damage, changes in habitat conditions) and a narrow ecological optimum - has been under legal protection in Poland since 1957 (Regulation of the Minister of the Environment 2014). Despite the fact that bladdernut is regionally endangered in Poland, the species is not included in the Red List in Poland (Kaźmierczakowa et al. 2016), even though it is considered endangered in the surrounding countries - Czech Republic, Slovakia and Ukraine (Melnyk et al. 2009; Eliáš et al. 2015; Grulich 2017). On a regional scale in Poland, this species has a various status depending on the region (Kącki et al. 2003; Nowak et al. 2009; Bróż \& Przemyski 2009; Parusel \& Urbisz 2012; Oklejewicz et al. 2015; Cwener et al. 2016).

A breakthrough in bladdernut research was Gostyńska's (1961) extensive work covering its distribution, ecology and morphology more broadly. Thanks to this fundamental work, we know that bladdernut occurs in Poland mainly in three regions: Sudety Mts \& Sudety Foreland, the Kraków-Częstochowa Upland and Western Carpathians. The largest number of species sites can be found in the Western Carpathians. This region is dominated by sites rich in individuals and the species distribution is well described (Kornaś et al. 1996; Kozłowska 2000; Oklejewicz et al. 2008; Jaźwa \& Stadnicka-Futoma 2014; Wolanin 2014). Bladdernut represents the southern, thermophilic sub-Mediterranean sub-element in our flora (Pawłowska 1972; Zając \& Zając 2009). Most studies on bladdernut cover the distribution and description of new sites of the species (Kornaś \& Wróbel 1972; Malik \& Nogawka 1999; Oklejewicz et al. 2008; Towpasz 2011; Piechnik et al. 2020). In recent years, there have been reports of new bladdernut sites, which prompted this research. This paper is intended to clarify the recent distribution of bladdernut in Poland.

\section{Material and methods}

The project concerning bladdernut chorology started in 2018. This paper reports data on its distribution gathered in the first stage of the investigations. The study was conducted between 2018-2021 in Poland. Data on the distribution of bladdernut sites were collected by a review of literature sources: scientific publications and additionally Master's theses, $\mathrm{PhD}$ dissertations, nature protection plans, databases of the forest districts, national parks, and Regional Directorates for Environmental Protection. The authors' search employed multidisciplinary methods such as: analysis of historical maps, use of the LIDAR map (Geoportal) to find terrain deformations (ravines, ditches and ramparts of strongholds, kurgans, building foundations) in forests. Some herbarium (KRAM, POZ) collections were reviewed. Research institute and museum databases were browsed. Data searching via correspondence and personal communications from scientists (mainly botanists and archaeologists), foresters and amateur naturalists were performed. Queries were posted in publications, internet nature forums, blogs and on Facebook. Databases of ethnographic museums were searched and information from ethnologists was obtained primarily in the area near villages where the traditions associated with bladdernut are still practiced (e.g., Easter palms, wooden or seed products). In areas of which there were former (often already extinct) sites of bladdernut - posters were attached to notice boards and interviews were conducted with local people. Bladdernut site searches were carried out using Google Street View.

All of the obtained information about the sites was confirmed by a field visit. Every bladdernut site identified was characterized in detail, specifying the geographic coordinates (using a GPS receiver) and describing the basic topographic data: slope, exposure, height above sea level. The size of the species population and the area it occupied were determined at each site. We described the habitat in most of the sites. The number of individuals in the patch and the height of the bushes were determined. Flowering, fruiting, shoot and root suckers, as well as seedlings, were noted. The health status, biotics and anthropogenic damage were recorded. The sites were described in accordance with generally accepted rules, giving them the names of the nearest towns or geographical objects. When verifying bladdernut sites known from the literature, the names of the authors who first mentioned these sites were given next to each of them, as well as those authors who later provided more information. The literature often mentioned only the general name of the site, covering a very large area with no data on bladdernut abundance or location detail.

In the case of sites of anthropogenic origin, an interview was conducted with the owners or managers of the site about the origin and age of the specimens. We have made every effort to inventory only old sites of anthropogenic origin, avoiding young plantings in private gardens and public greenery. We did not search for a bladdernut sites in palace and manor parks, both maintained and neglected. In the list of sites, shrubs of unknown origin and those purchased in garden centers or forest nurseries were not taken into account. Similarly, we omitted modern bladdernut plantings in forests, because there have been several dozen cases of introducing bladdernut into forests in Poland.

In the description of each site, the following layout was adopted within the physico-geographical sub-provinces: 


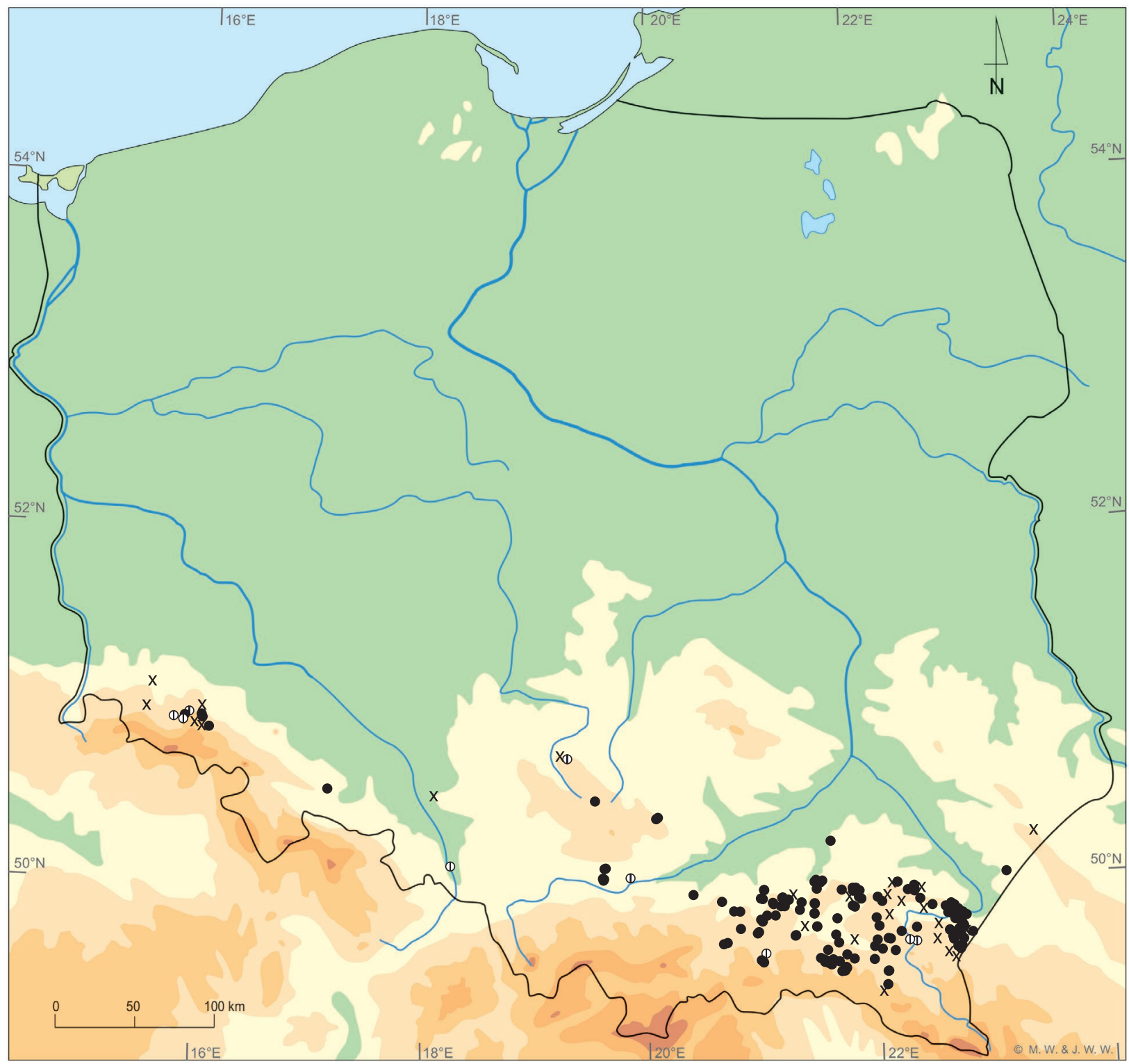

Figure 1. The current, natural distribution of European bladdernut Staphylea pinnata in Poland. Sites considered as natural - black dots, sites with undetermined status - crossed circles, unconfirmed sites - x marks.

mesoregion, asterisk $\left({ }^{*}\right)$ of a site of anthropogenic origin (optional), name of the site, exclamation mark (!) of an unpublished site (optional), geographical coordinates, altitude, abbreviated characteristics of the site (number of individuals, general information on topography and habitat), information about the origin of the anthropogenic site (optional), and literature (or unpublished data) describing the site.

On the distribution maps (Figs 1-2), the signs of both natural and anthropogenic origin sites, were differentiated. The physico-geographical mesoregions of Poland were adopted in accordance with the work of Solon et al. (2018), because they are compatible with the Geoportal service, which is widely used in nature conservation. The bladdernut develops numerous shoot and root suckers that can grow up to several meters from the parent specimen. Without the use of molecular methods, it is very difficult to accurately determine the number of separate individuals in the field. Therefore, when specifying the number of individuals, the term shoot was used in most natural sites. In turn, in most cases of sites of anthropogenic origin, the term shrub was used where a single specimen was found.

\section{Results}

We found that the bladdernut in Poland has occurred at 354 sites in total (Figs 1-2), situated in: the Southern Baltic Coastlands (Pobrzeża Południowobałtyckie), Central Poland Lowlands (Niziny Środkowopolskie), Sudety Mts \& Sudety Foreland (Sudety z Przedgórzem Sudeckim), Silesia-Kraków Upland (Wyżyna Śląsko-Krakowska), Małopolska Upland (Wyżyna Małopolska), Lublin-Lviv Upland (Wyżyna Lubelsko-Lwowska), Northern Subcarpathians (Podkarpacie Północne), Outer Western Carpathians (Zewnętrzne Karpaty Zachodnie), Eastern Subcarpathians (Wschodnie Podkarpacie), Outer Eastern Carpathians (Zewnętrzne Karpaty Wschodnie) and the Eastern Baltic Lake District (Pojezierze Wschodniobałtyckie). 164 new, unpublished sites of the species were 


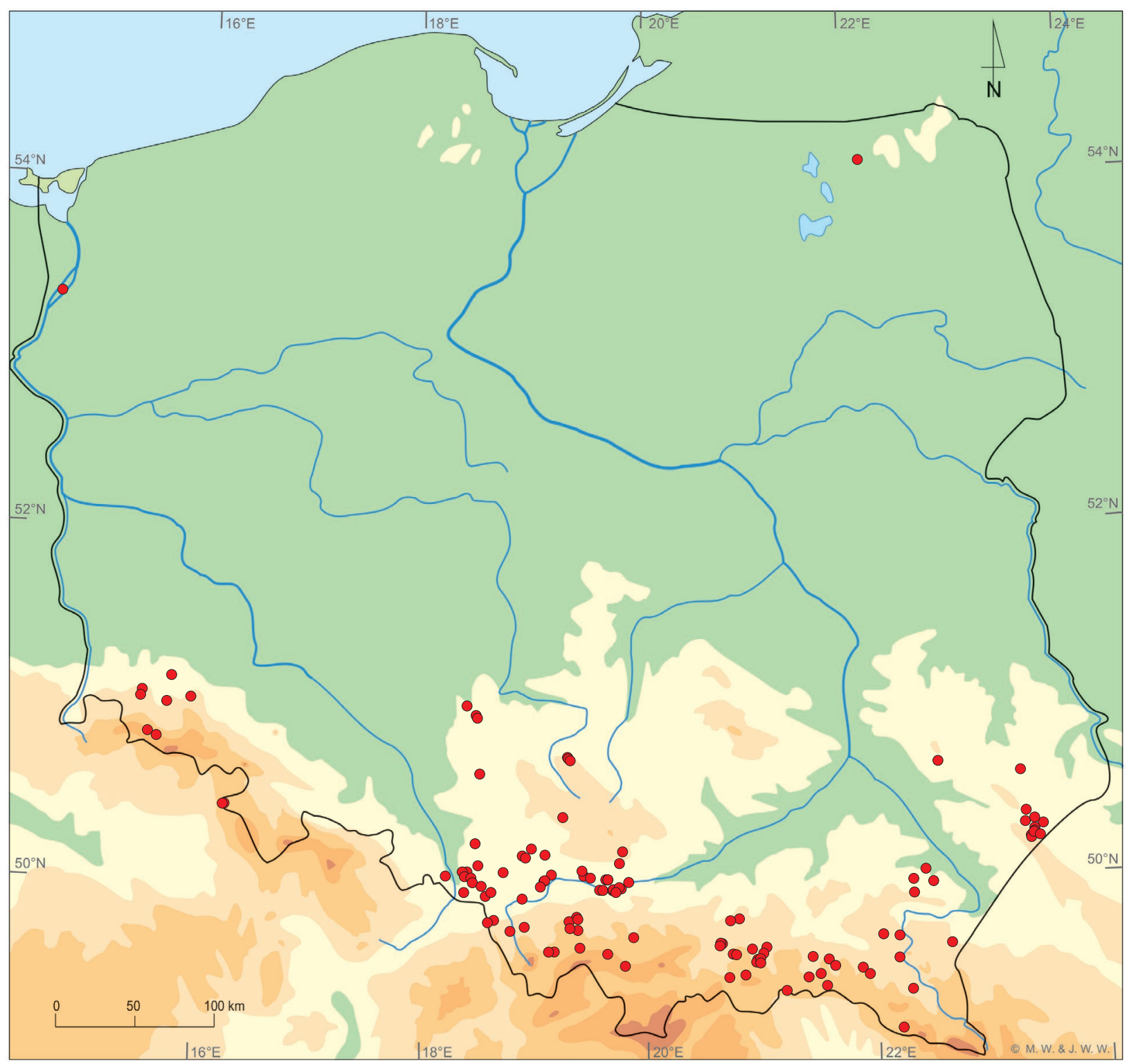

Figure 2. The current distribution of European bladdernut Staphylea pinnata sites, considered as an anthropogenic origin in Poland (red dots).

found, and a detailed list and description of all of the new sites is presented below.

specimens examined. SOUTHERN BALTIC COASTLANDS. Wełtyń Plain:- ${ }^{*}$ Wietrzne Góry (!) $53^{\circ} 18^{\prime} 41.8^{\prime \prime} \mathrm{N}$, $14^{\circ} 34^{\prime} 28.1^{\prime \prime} \mathrm{E}, 50 \mathrm{~m}$ a.s.1., $2 \mathrm{~km}$ north of Stare Brynki. Dozens of shoots of various ages (including fruiting ones) on the top of a moraine in an overexposed oak-hornbeam forest with a large share of oak. The origin is unknown (Pluciński P. - unpubl. data).

CENTRAL POLAND LOWLANDS. Racibórz Gate: — Racibórz, $50^{\circ} 04^{\prime} 54.4^{\prime \prime} \mathrm{N}, 18^{\circ} 13^{\prime} 54.8^{\prime \prime} \mathrm{E}, 190 \mathrm{~m}$ a.s.l., one at least 80-year-old shrub near an old building (Duda 1997). - Łężczok, $50^{\circ} 07^{\prime} 55.5^{\prime \prime} \mathrm{N}, 18^{\circ} 16^{\prime} 18.2^{\prime \prime} \mathrm{E}, 190 \mathrm{~m}$ a.s.l., over a dozen shrubs in oak-hornbeam forest, near Babiczak Południowy Pond, in the Lężczok Nature Reserve. The origin of the specimens is unknown, site of undetermined status (Celiński 1994). Opole Plain:- Koszwice (!), 50³9'30.5' N, 18 ${ }^{\circ} 31^{\prime} 40.6^{\prime \prime} \mathrm{E}, 220 \mathrm{~m}$ a.s.l., one at least 80 -year-old shrub near the ruins of the farm.

SUDETY MOUNTAINS \& SUDETY FORELAND. Strzegom Hills:-Las Cieszanowicki (!), 50³3'43.4"N, $17^{\circ} 10^{\prime} 29.8^{\prime \prime} \mathrm{E}, 305 \mathrm{~m}$ a.s.1., a few shoots in a 60 -year-old oak-hornbeam forest. Near the edge of the forest (FMP Prudnik 2010). Izerskie Foothills:- ${ }^{*}$ Gradówek (!), 51 ${ }^{\circ} 05^{\prime} 26.2^{\prime \prime} \mathrm{N}$, $15^{\circ} 30^{\prime} 05.4^{\prime \prime} \mathrm{E}, 280 \mathrm{~m}$ a.s.1., about 110 shoots on the ruins of two houses (Rogowski G. - unpubl. data).- - Nagórze (!), $51^{\circ} 03^{\prime} 24.6^{\prime \prime} \mathrm{N}, 15^{\circ} 29^{\prime} 21.3^{\prime \prime} \mathrm{E}, 370 \mathrm{~m}$ a.s.1., one, at least 80 years old, shrub on the ruins of a house. Kaczawskie Foothills:- ${ }^{*}$ Kondratów (!), $51^{\circ} 03^{\prime} 33.1^{\prime \prime} \mathrm{N}, 15^{\circ} 56^{\prime} 19.9^{\prime \prime} \mathrm{E}, 300 \mathrm{~m}$ a.s.l., about 20 shoots on the ruins of the old water mill (Konieczny K. - unpubl. data).- - Wzgórze Grodziec, $51^{\circ} 10^{\prime} 33.5^{\prime \prime} \mathrm{N}, 15^{\circ} 45^{\prime} 31.7^{\prime \prime} \mathrm{E}$, $370 \mathrm{~m}$ a.s.1., one shrub on the rampart next to a Grodziec Castle. Origin and age were not specified (Kwiatkowski 1996; Boratyński \& Kwiatkowski 1998).- - Bystrzyca (!), 5101'43.8"N, $15^{\circ} 43^{\prime} 28.9^{\prime \prime} \mathrm{E}, 370 \mathrm{~m}$ a.s.1., one old shrub (at least 80 years) and two shoots in the thickets near the closed Evangelical church. Wałbrzyskie Foothills:-Dębowa Góra, 5053'36.0”N, $16^{\circ} 06^{\prime} 38.4^{\prime \prime} \mathrm{E}, 405 \mathrm{~m}$ a.s.1., a few shoots in the edge of the oak forest (Gostyńska 1961; Boratyński \& Kwiatkowski 1998; Mularczyk T. - unpubl. data). Izerskie Mts:- ${ }^{*}$ Górzyniec (!), $50^{\circ} 51^{\prime} 34.4^{\prime \prime} \mathrm{N}, 15^{\circ} 33^{\prime} 53.5^{\prime \prime} \mathrm{E}, 460 \mathrm{~m}$ a.s.1., one old shrub (at least 90 -years-old) in the area of an inhabited farm (Narkiewicz C. - unpubl. data). Kaczawskie Mts:-Nowe Rochowice (!), $50^{\circ} 56^{\prime} 38.0^{\prime \prime} \mathrm{N}, 16^{\circ} 03^{\prime} 04.4^{\prime \prime} \mathrm{E}, 450 \mathrm{~m}$ a.s.1., about 70 shoots in a 60-year-old ash-oak forest on the old quarry slopes (FMP Jawor 2018).-Bukowa Góra, 5057'41.4" N, $16^{\circ} 02^{\prime} 28.8^{\prime \prime} \mathrm{E}$, 390-410 m a.s.l., about 100 shoots above the edge of the 
former quarry in beech-oak forest (Fiek 1881; Schube 1904; Gostyńska 1961; Boratyński \& Kwiatkowski 1998; Kwiatkowski \& Budzyn 2001; FMP Jawor 2018)._Podgórki (!), $50^{\circ} 57^{\prime} 13.4^{\prime \prime} \mathrm{N}, 15^{\circ} 53^{\prime} 33.3^{\prime \prime} \mathrm{E}, 495 \mathrm{~m}$ a.s.l., about 30 shoots in pine beech forest on the old quarry slope (Narkiewicz C. unpubl. data).-Komarno (!), 50 $55^{\prime} 30.9^{\prime \prime} \mathrm{N}, 15^{\circ} 53^{\prime} 08.1^{\prime \prime} \mathrm{E}$, $545 \mathrm{~m}$ a.s.1. a few shoots in the edge of the oak forest. Origin unknown, site of undetermined status (Frankowski D. - unpubl.

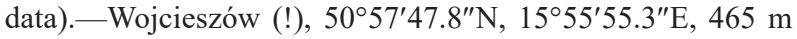
a.s.l., one compact cluster of about 110 shoots in a beech forest. Origin unknown, site of undetermined status (Rogowski G. unpubl. data).-Dziwiszów (!), 5056'27.1"N $15^{\circ} 48^{\prime} 00.3^{\prime \prime} \mathrm{E}$, $470 \mathrm{~m}$ a.s.l., about 20 shoots growing under the power line in the forest. On the border of oak-hornbeam forest and Norway spruce plantations. Origin unknown, site of undetermined status (Kalemba K. - unpubl. data). Karkonosze Mts:- ${ }^{*}$ Chojnik, $50^{\circ} 50^{\prime} 04.5^{\prime \prime} \mathrm{N}, 15^{\circ} 38^{\prime} 41.6^{\prime \prime} \mathrm{E}, 605 \mathrm{~m}$ a.s.l., five shoots in a beech forest, opposite the main gate to Chojnik Castle, in the Karkonosze National Park area. The origin and age were not specified (Konca 1991; Boratyński \& Kwiatkowski 1998). Stołowe Mts:- ${ }^{*}$ Pstrążna, 50 27'55.2"N, 16 $16^{\circ} 13.8^{\prime \prime} \mathrm{E}, 535 \mathrm{~m}$ a.s.l., a few shrubs on the ruins of a farm house in the Stołowe Mountains National Park area (Boratyński \& Kwiatkowski 1998).- - Czermna, 50 $27^{\prime} 48.4^{\prime \prime} \mathrm{N}, 16^{\circ} 15^{\prime} 17.3^{\prime \prime} \mathrm{E}, 455 \mathrm{~m}$ a.s.l., one at least 70-year-old shrub next to an inhabited house (Boratyński \& Kwiatkowski 1998).

SILESIA-KRAKÓW UPLAND. Katowice Upland:-

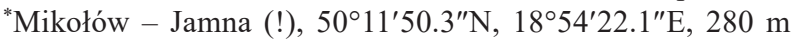
a.s.l., one shrub next to the fence of an old farm (Wierzgon M. - unpubl. data).- ${ }^{*}$ Katowice - Zarzecze (!), 50 $11^{\prime} 09.4^{\prime \prime} \mathrm{N}$, $18^{\circ} 56^{\prime} 04.4^{\prime \prime}$ E, $285 \mathrm{~m}$ a.s.1., one old shrub (at least 90 -years-old) in the area of an inhabited farm (Wierzgon M. - unpubl. data).- Katowice - Brynów (!), 50 $14^{\prime} 12.6^{\prime \prime} \mathrm{N}, 18^{\circ} 59^{\prime} 10.8^{\prime \prime} \mathrm{E}$, $300 \mathrm{~m}$ a.s.l., two shrubs in the fence of an old farm (Urban J. - unpubl. data)._- Mysłowice Stara Wesoła (!), 50¹2'07.7"N, $19^{\circ} 06^{\prime} 20.6^{\prime \prime} \mathrm{E}, 300 \mathrm{~m}$ a.s.1., one old shrub (at least 150-years-old) in the area of an inhabited farm (Duda I. - unpubl. data). Jaworzno Knolls:- ${ }^{*}$ Las Trzebiesławicki, 50²4'49.5"N, $19^{\circ} 15^{\prime} 48.2^{\prime \prime} \mathrm{E}, 325 \mathrm{~m}$ a.s.l., two old shrubs on an overgrown midforest meadow and on the site of former building. Origin and age were not specified (Rutkowska 2013; Tyc A. - unpubl. data). Rybnik Plateau:- - ${ }^{*}$ Gaszowice - Cegielnia (!), $50^{\circ} 06^{\prime} 22.0^{\prime \prime} \mathrm{N}$, $18^{\circ} 25^{\prime} 17.9^{\prime \prime} \mathrm{E}, 240 \mathrm{~m}$ a.s.l., one old shrub (min. 100 years) in the area of an inhabited farm (Adamczyk B. \& Kolorz Z. - unpubl. data).--'Lyski (!), $50^{\circ} 06^{\prime} 21.5^{\prime \prime} \mathrm{N}, 18^{\circ} 22^{\prime} 47.3^{\prime \prime} \mathrm{E}, 240 \mathrm{~m}$ a.s.1., one, min. 100-year-old, shrub in the area of an inhabited farm (Adamczyk B. \& Kolorz Z. - unpubl. data) (Fig. 3H).- ${ }^{*}$ Czernica (!), $50^{\circ} 04^{\prime} 45.1^{\prime \prime} \mathrm{N}, 18^{\circ} 23^{\prime} 59.0^{\prime \prime} \mathrm{E}, 240 \mathrm{~m}$ a.s.l., one old shrub (min. 100 years) next to an inhabited building from the beginning of the $20^{\text {th }}$ century (Adamczyk B. \& Kolorz Z. unpubl. data).- ${ }^{*}$ Rydułtowy - Radoszowy (!), 5004'19.4"N, $18^{\circ} 27^{\prime} 20.3^{\prime \prime}$ E, $275 \mathrm{~m}$ a.s.1., one old shrub (min. 100-year-old) next to an inhabited building (Adamczyk B. \& Kolorz Z. unpubl. data).- ${ }^{*}$ Radlin (!), $50^{\circ} 02^{\prime} 43.8^{\prime \prime} \mathrm{N}, 18^{\circ} 28^{\prime} 09.1^{\prime \prime} \mathrm{E}$, $280 \mathrm{~m}$ a.s.l., one, min. 80-year-old, shrub in the fence next to an inhabited house (Adamczyk B. \& Kolorz Z. - unpubl. data).--Palowice (!), 50 $06^{\prime} 12.7^{\prime \prime} \mathrm{N}, 18^{\circ} 44^{\prime} 18.4^{\prime \prime} \mathrm{E}, 285 \mathrm{~m}$ a.s.1., one shrub and few small shoots in the oak-pine forest next to the forest road. The origin is unknown.- ${ }^{*}$ Marklowice (!), $50^{\circ} 01^{\prime} 30.9^{\prime \prime} \mathrm{N}, 18^{\circ} 32^{\prime} 46.0^{\prime \prime} \mathrm{E}, 280 \mathrm{~m}$ a.s.1., one shrub on the ruins of a farm house.- ${ }^{*}$ Rybnik - Grabownia a (!), $50^{\circ} 08^{\prime} 30.5^{\prime \prime} \mathrm{N}$, $18^{\circ} 31^{\prime} 00.6^{\prime \prime} \mathrm{E}, 225 \mathrm{~m}$ a.s.1., one old shrub in the yard, which formerly a farm (Bulandra J. \& Bulandra S. - unpubl. data).- - Rybnik - Grabownia b (!), 5008'29.4"N, $18^{\circ} 30^{\prime} 56.2^{\prime \prime} \mathrm{E}, 230 \mathrm{~m}$ a.s.l., one old shrub in the yard, which formerly a farm $(\mathrm{Bu}-$ landra J. \& Bulandra S. - unpubl. data).- - Rybnik - Grabownia c (!), $50^{\circ} 08^{\prime} 22.3^{\prime \prime} \mathrm{N}, 18^{\circ} 31^{\prime} 30.4^{\prime \prime} \mathrm{E}, 245 \mathrm{~m}$ a.s.1., one old shrub in the yard, which formerly a farm (Bulandra J. \& Bulandra S. unpubl. data).- 'Z Zwonowice (!), 5008'39.6"N $18^{\circ} 26^{\prime} 30.9^{\prime \prime} \mathrm{E}$, $250 \mathrm{~m}$ a.s.1., one old shrub in the yard, which formerly a farm (Krotoski T. - unpubl. data).- ${ }^{*}$ Jejkowice (!), $50^{\circ} 06^{\prime} 15.8^{\prime \prime} \mathrm{N}$, $18^{\circ} 28^{\prime} 37.4^{\prime \prime}$ E, $235 \mathrm{~m}$ a.s.l., one old shrub next to an inhabited building.- - Czyżowice (!), 4959'23.1”N, 18²3'38.6"E, $270 \mathrm{~m}$ a.s.1., two old (min. 50-year-old) shrubs in the area of an inhabited forester's lodge (Rebeś J. - unpubl. data).- - Jastrzębie Zdrój Pochwacie (!), 49 58'07.4"N , 18³4'58.5"E, 280 m a.s.1., one 70-year-old shrub next to an inhabited building.- - Jastrzębie Zdrój - Szeroka (!), 4959'28.4"N, 18³7'55.3"E, 260 m a.s.l., one 50-year-old shrub in the area of inhabited farm (Bogusz W. - unpubl. data). Bojszów Depression:- ${ }^{*}$ Trachy (!), $50^{\circ} 15^{\prime} 42.9^{\prime \prime} \mathrm{N}, 18^{\circ} 29^{\prime} 48.2^{\prime \prime} \mathrm{E}, 225 \mathrm{~m}$ a.s.l., two shoots in the place of a former forest lodge (Ciemny K. - unpubl. data). Herby

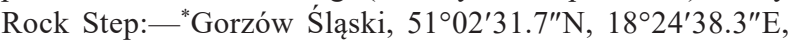
$195 \mathrm{~m}$ a.s.l., six old shrubs on the ruins of a farm (Central Register 2021).- - Kościeliska a, 5059'18.9"N, 18²9'33.5"E, $225 \mathrm{~m}$ a.s.1., one old (min. 50 years) shrub in the area of an inhabited old farm (Gostyńska 1961; Kuczyńska 1974).-— Kościeliska b, $50^{\circ} 58^{\prime} 24.4^{\prime \prime} \mathrm{N}, 18^{\circ} 30^{\prime} 16.9^{\prime \prime} \mathrm{E}, 250 \mathrm{~m}$ a.s.1., one old (min. 50 years) shrub in the area of an inhabited old farm (Gostyńska 1961; Kuczyńska 1974). Częstochowa Upland:Sokole Góry (Knieja), 5044'11.6"N, 19¹7'54.7"E, $340 \mathrm{~m}$ a.s.1., one old shrub growing on the edge of a beech forest. Origin and age unknown, site of undetermined status (Hereźniak 1993; FMP Złoty Potok 2016).-- Przymiłowice, 5045'09.7"N, $19^{\circ} 18^{\prime} 26.0^{\prime \prime} \mathrm{E}, 320 \mathrm{~m}$ a.s.1., one, min. 110 -year-old, shrub next to an inhabited building (Wóycicki 1914; Hyla 1938; Gostyńska 1961; Hereźniak 1983).—“Podkotysów a (!), 5044'44.4"N, $19^{\circ} 18^{\prime} 37.0^{\prime \prime} \mathrm{E}, 320 \mathrm{~m}$ a.s.1.- Podkotysów b (!), 50 $44^{\prime} 42.0^{\prime \prime} \mathrm{N}$, $19^{\circ} 18^{\prime} 43.3^{\prime \prime} \mathrm{E}, 325 \mathrm{~m}$ a.s.1.- ${ }^{*}$ Podkotysów c (!), 5044'42.2"N, $19^{\circ} 18^{\prime} 53.2^{\prime \prime} \mathrm{E}, 325 \mathrm{~m}$ a.s.1.- Podkotysów d (!), 5044'42.1"N, $19^{\circ} 18^{\prime} 54.7^{\prime \prime} \mathrm{E}, 325 \mathrm{~m}$ a.s.l. The sites in Podkotysów are within the old inhabited farms. The age of the shrubs is not exactly known; they vary from 20 to 80 years.-Las Żerkowicki, $50^{\circ} 30^{\prime} 06.9^{\prime \prime} \mathrm{N}, 19^{\circ} 32^{\prime} 09.4^{\prime \prime} \mathrm{E}, 325 \mathrm{~m}$ a.s.l., one shrub growing at the base of a limestone rock (Malik 2012), previously reported as 'Skałki w lesie pod Karlinem' (Kaznowski 1922; Kaznowski 1929).-- Zrębice, 5044'02.6"N, 19¹9'51.5"E, $335 \mathrm{~m}$ a.s.1., one, min. 50-year-old, shrub next to an inhabited building (Gostyńska 1961; Hereźniak 1993). Olkusz Upland:-—"Sąspów (!), $50^{\circ} 13^{\prime} 05.1^{\prime \prime} \mathrm{N}, 19^{\circ} 47^{\prime} 15.8^{\prime \prime} \mathrm{E}, 335 \mathrm{~m}$ a.s.l., one shrub on the ruins of farm buildings in the Ojców National Park area.- Kobylany (!), $50^{\circ} 09^{\prime} 07.1^{\prime \prime} \mathrm{N}, 19^{\circ} 45^{\prime} 32.9^{\prime \prime} \mathrm{E}, 288 \mathrm{~m}$ a.s.l., one shrub in the fence of an old abandoned farm. Tenczynek Hills:Tenczynek - Buczyna, 5007'17.9' N, 19³6'54.4"E, $340 \mathrm{~m}$ a.s.1., a shoots cluster with an area of approximately $1,300 \mathrm{~m}^{2}$ in a 180-year-old beech-hornbeam forest. On the plateau and S-W parts of the hill (Malik \& Nogawka 1998), previously reported as 'Góra Piaski' (Oklejewicz et al. 2008). - Tenczynek - Poneklica, $50^{\circ} 07^{\prime} 27.3^{\prime \prime} \mathrm{N}, 1^{\circ} 37^{\prime} 32.6^{\prime \prime} \mathrm{E}, 340 \mathrm{~m}$ a.s.l., a few shoots in a 160 -year-old pine-beech forest. Near the edge of the forest, at the base of limestone rocks (Malik \& Nogawka 1999).-Baczyn (!), 5005'32.7'N , 1940'34.6"E, $335 \mathrm{~m}$ a.s.1., a few shoots in two distinct clusters growing on limestone rocks in an beech forest (Dziadowiec A. \& Kulpa M. - unpubl.

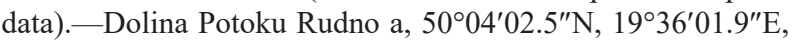
300-310 m a.s.1., about 60 shoots in three distinct clusters at the foot of limestone rocks in an oak-beech forest (Zarzycki 1959; Gostyńska 1961; Drużkowski \& Dubiel 1994; Malik \& Nogawka 1998).-Dolina Potoku Rudno b, 5003'49.3"N, 19³6'39.7"E, 310-320 m a.s.l., about 120 shoots growing dispersed, mainly in ravines that cut across the entire area, in a beech-pine forest with an admixture of hornbeam (Gostyńska 1961; Drużkowski 
\& Dubiel 1994; Malik \& Nogawka 1998).-Dolina Wrzosy, $50^{\circ} 03^{\prime} 25.1^{\prime \prime} \mathrm{N}, 19^{\circ} 36^{\prime} 19.4^{\prime \prime} \mathrm{E}, 270 \mathrm{~m}$ a.s.l., several dozen shoots growing on limestone rocks, in xerothermic bushes and in an oak forest (Gostyńska 1961; Drużkowski \& Dubiel 1994; Malik \& Nogawka 1998).- Rybna a, 5003'40.1"N, 19³8'17.6"E, 330 m a.s.1., one shrub on a farm ruins (Gostyńska 1961; Malik \& Nogawka 1999).- 'Rybna b, 5003'33.4"N, 19³8'21.4"E, $310 \mathrm{~m}$ a.s.l., one shrub in the place of a former house (Gostyńska 1961; Malik \& Nogawka 1999).- - Rybna c, 5003'40.3"N, $19^{\circ} 39^{\prime} 23.6^{\prime \prime} \mathrm{E}, 345 \mathrm{~m}$ a.s.1., two old shrubs in the fence of an inhabited farm (Gostyńska 1961; Malik \& Nogawka 1999)."Rybna d, 5003'38.8"N, 19³9'20.4"E, 340 m a.s.l., one old shrub in the area of inhabited farm (Gostyńska 1961; Malik \& Nogawka 1999).- - Kamień (!), 5000'10.5”N, 19³5'00.7"E, $225 \mathrm{~m}$ a.s.l., one old (min. 80-year-old) shrub in the area of an inhabited farm in the place of a former house.- ${ }^{*}$ Rusocice a (!), 50 $00^{\prime} 07.4^{\prime \prime} \mathrm{N}, 19^{\circ} 35^{\prime} 34.6^{\prime \prime} \mathrm{E}, 240 \mathrm{~m}$ a.s.l., one, 50-year-old shrub in the area of an inhabited farm.- ${ }^{*}$ Płaza, $50^{\circ} 04^{\prime} 56.6^{\prime \prime} \mathrm{N}$, $19^{\circ} 26^{\prime} 44.6^{\prime \prime} \mathrm{E}, 280 \mathrm{~m}$ a.s.l., one old (min. 80 years) shrub in the place of a former building (Malik \& Nogawka 1999) (Fig. 3E).- - Kwaczała (!), 5004'24.7"N, 19³0'27.9" E, $305 \mathrm{~m}$ a.s.l., one old (min. 80 years) shrub in the area of an inhabited farm (Garlicki S. - unpubl. data).

MAŁOPOLSKA UPLAND. Miechów Upland:-Cisie a, $50^{\circ} 24^{\prime} 22.2^{\prime \prime} \mathrm{N}, 20^{\circ} 05^{\prime} 16.4^{\prime \prime} \mathrm{E}, 300 \mathrm{~m}$ a.s.l., about 300 shoots growing on the W and SW slopes of a hill, near the edge of a beech - hornbeam forest with an admixture of birch and Scots pine (Filkowa 1987) (Fig. 3A).-Cisie b, 50²3'55.2"N, $20^{\circ} 04^{\prime} 21.4^{\prime \prime} \mathrm{E}, 380 \mathrm{~m}$ a.s.1., about 100 shoots growing on the western, gentle slope of a hill in a beech forest with an admixture of hornbeam (Filkowa 1987).

LUBLIN-LVIV UPLAND. Western Roztocze:- ${ }^{*}$ Kocudza - Bielaki (!), 5040'33.4" N, 22 36'29.3"E, $230 \mathrm{~m}$ a.s.1., one old shrub in the area of an inhabited farm (Pędziwiatr A. unpubl. data). Eastern Roztocze:- ${ }^{*}$ Borysy (!), 50¹8'09.8"N, $23^{\circ} 29^{\prime} 42.7^{\prime \prime} \mathrm{E}, 295 \mathrm{~m}$ a.s.1., about 70 shoots in a beech-pine forests on the ruins of the former Ukrainian village of Borysy.- Dahany I, $50^{\circ} 16^{\prime} 37.8^{\prime \prime} \mathrm{N}, 23^{\circ} 25^{\prime} 05.6^{\prime \prime} \mathrm{E}, 300 \mathrm{~m}$ a.s.l., one shrub in a pine forest on a building ruins in the area of the former Ukrainian village of Dahany (Gostyńska 1961).- - Sołtysy (!), $50^{\circ} 14^{\prime} 08.7^{\prime \prime} \mathrm{N}, 23^{\circ} 23^{\prime} 01.0^{\prime \prime} \mathrm{E}, 310 \mathrm{~m}$ a.s.l., over a hundred large shoots in an oak-hornbeam forest on the ruins of the former Ukrainian village of Sołtysy (Fig. 3F). - ${ }^{*}$ Niedźwiedzie (!), $50^{\circ} 15^{\prime} 36.4^{\prime \prime} \mathrm{N}, 23^{\circ} 24^{\prime} 58.0^{\prime \prime} \mathrm{E}, 325 \mathrm{~m}$ a.s.l., several dozen large shoots on the ruins of the former Ukrainian village of Niedźwiedzie.- - Nowiny Horynieckie a (!), 50¹3'28.0"N, $23^{\circ} 23^{\prime} 06.4^{\prime \prime} \mathrm{E}, 295 \mathrm{~m}$ a.s.l., one old shrub in garden in the area of an inhabited farm. - Nowiny Horynieckie b (!), 50 $0^{\circ} 13^{\prime} 31.1^{\prime \prime} \mathrm{N}$, $23^{\circ} 23^{\prime} 38.3^{\prime \prime} \mathrm{E}, 310 \mathrm{~m}$ a.s.l., one old shrub in a garden in the area of an inhabited farm. - ${ }^{*}$ Lasowa, $50^{\circ} 15^{\prime} 11.8^{\prime \prime} \mathrm{N}, 23^{\circ} 24^{\prime} 29.3^{\prime \prime} \mathrm{E}$, $330 \mathrm{~m}$ a.s.1., about 50 shoots in a beech-pine forest on the ruins of the former Ukrainian village of Lasowa (Bajda 2009).—- ${ }^{*}$ użki (!), $50^{\circ} 14^{\prime} 13.5^{\prime \prime} \mathrm{N}, 23^{\circ} 27^{\prime} 46.6^{\prime \prime} \mathrm{E}, 290 \mathrm{~m}$ a.s.1., about 50 shoots in a beech-pine forests on the ruins of the former Ukrainian village of Łużki.- - ${ }^{*}$ Chmiele (!), $50^{\circ} 15^{\prime} 38.1^{\prime \prime} \mathrm{N}, 23^{\circ} 22^{\prime} 55.4^{\prime \prime} \mathrm{E}, 340 \mathrm{~m}$ a.s.l., a few shoots in a sycamore-ash forest on the ruins of the former Ukrainian village of Chmiele.- - Juchy (!), 50 $0^{\circ} 15^{\prime} 53.9^{\prime \prime} \mathrm{N}$, $23^{\circ} 24^{\prime} 06.0^{\prime \prime} \mathrm{E}, 345 \mathrm{~m}$ a.s.1., a few shoots in a beech-pine forest on the ruins of the former Ukrainian village of Juchy.- ${ }^{*}$ Sochanie (!), $50^{\circ} 16^{\prime} 25.4^{\prime \prime} \mathrm{N}, 23^{\circ} 22^{\prime} 33.8^{\prime \prime} \mathrm{E}, 350 \mathrm{~m}$ a.s.l., about 40 shoots in a pine forest on the ruins of the former Ukrainian village of Sochanie.- 'Majdan (!), 50 $17^{\prime} 08.7^{\prime \prime} \mathrm{N}, 23^{\circ} 22^{\prime} 48.1^{\prime \prime} \mathrm{E}, 360 \mathrm{~m}$ a.s.1., about 20 shoots in a larch-pine forest on the ruins of the former Ukrainian village of Majdan. - ${ }^{*}$ ozy (!), 50²0'39.9" $\mathrm{N}$, $23^{\circ} 16^{\prime} 26.6^{\prime \prime} \mathrm{E}, 320 \mathrm{~m}$ a.s.1., one shrub in a in a beech-pine forest.

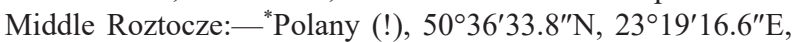

$280 \mathrm{~m}$ a.s.l., one old shrub in the area of an inhabited farm (Wiśniewska K. - unpubl. data).

NORTHERN SUBCARPATHIANS. Kończyce Upland:— Kończyce Wielkie (!), 4950'01.6"N, 18³9'24.2"E, $255 \mathrm{~m}$ a.s.1., one 80-year-old shrub in the area of an abandoned farm.- - Pogwizdów (!), 4949'13.5"N, 18³6'10.8"E, $280 \mathrm{~m}$ a.s.l., one 80-year-old shrub in the area of an inhabited

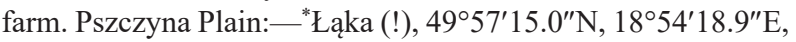
$265 \mathrm{~m}$ a.s.l., one 80-year-old shrub in the area of an inhabited farm.- - Bieruń Nowy (!), 5005'23.2"N, $19^{\circ} 09^{\prime} 41.9^{\prime \prime} \mathrm{E}$, $235 \mathrm{~m}$ a.s.l., one unknown aged shrub in the area of an inhabited farm. Upper Vistula River Valley:- ${ }^{*}$ Bojszowy a (!), $50^{\circ} 03^{\prime} 27.8^{\prime \prime} \mathrm{N}, 19^{\circ} 06^{\prime} 09.9^{\prime \prime} \mathrm{E}, 235 \mathrm{~m}$ a.s.l., two unknown aged shrubs in the area of an inhabited farm.- Bojszowy b (!), $50^{\circ} 03^{\prime} 14.3^{\prime \prime} \mathrm{N}, 1^{\circ} 05^{\prime} 46.7^{\prime \prime} \mathrm{E}, 235 \mathrm{~m}$ a.s.l., one unknown aged shrub in the fence near the road. Skawina Deep:- ${ }^{*}$ Rusocice b (!), $50^{\circ} 00^{\prime} 05.3^{\prime \prime} \mathrm{N}, 19^{\circ} 36^{\prime} 43.7^{\prime \prime} \mathrm{E}, 215 \mathrm{~m}$ a.s.1., one unknown aged shrub in the area of an inhabited farm.- ${ }^{*}$ Zagacie a (!), $49^{\circ} 59^{\prime} 60.0^{\prime \prime} \mathrm{N}, 19^{\circ} 41^{\prime} 52.8^{\prime \prime} \mathrm{E}, 215 \mathrm{~m}$ a.s.l., one 30 -year-old shrub in the area of an inhabited farm.- Z Zagacie b (!), $50^{\circ} 00^{\prime} 18.3^{\prime \prime} \mathrm{N}$, $19^{\circ} 42^{\prime} 11.6^{\prime \prime} \mathrm{E}, 218 \mathrm{~m}$ a.s.1., one shrub of undefined age in an old garden. Cholerzyn Depression:- * Rączna a (!), 5000'33.7"N, $19^{\circ} 46^{\prime} 22.7^{\prime \prime} \mathrm{E}, 235 \mathrm{~m}$ a.s.1., one 50-year-aged shrub in the area of an inhabited farm. - Rączna b (!), 50 $00^{\prime} 59.4^{\prime \prime} \mathrm{N}, 19^{\circ} 45^{\prime} 20.8^{\prime \prime} \mathrm{E}$, $255 \mathrm{~m}$ a.s.l., one 60 -year-old shrub in the area of an inhabited farm.- Wołowice (!), 49 $59^{\prime} 21.2^{\prime \prime} \mathrm{N}, 19^{\circ} 43^{\prime} 33.2^{\prime \prime} \mathrm{E}, 210 \mathrm{~m}$ a.s.l., one 50-year-old shrub in the area of an inhabited farm. Cracow Bridge:-Las Wolski - Zakamycze, $50^{\circ} 03^{\prime} 53.8^{\prime \prime} \mathrm{N}$, $19^{\circ} 50^{\prime} 49.1^{\prime \prime} \mathrm{E}, 290 \mathrm{~m}$ a.s.1., two clusters of shoots in a beech forest, near to forest edge. The origin of specimens is unknown, site of undetermined status (Mleczko \& Padoł 2009; Medwecka Kornaś A. - unpubl. data).- ${ }^{*}$ Las Wolski - Srebrna Góra, $50^{\circ} 02^{\prime} 42.4^{\prime \prime} \mathrm{N}, 19^{\circ} 50^{\prime} 20.0^{\prime \prime} \mathrm{E}, 315 \mathrm{~m}$ a.s.1., one cluster of shoots within the monastery walls in a beech forest (Mleczko \& Padoł 2009). Kolbuszowa Plateau:-Buczyna w Cyrance, $50^{\circ} 15^{\prime} 13.7^{\prime \prime} \mathrm{N}, 21^{\circ} 35^{\prime} 52.0^{\prime \prime} \mathrm{E}, 265 \mathrm{~m}$ a.s.1., 10 shoots in a beech forest in a Nature Reserve area (Fabijanowski 1959; Dubiel et al. 1979). Tarnogród Plateau:- Lukawiec (!), 5002'39.5"N, $23^{\circ} 07^{\prime} 20.2^{\prime \prime} \mathrm{E}, 250 \mathrm{~m}$ a.s.1., 5 shrubs in an oak-hornbeam forest with large proportion of beech. Sub-Carpathian Ice Marginal Valley:- - Grzęska a (!), 5004'59.4"N, 22 ${ }^{\circ} 27^{\prime} 10.4^{\prime \prime} \mathrm{E}, 185 \mathrm{~m}$ a.s.l., one old shrub in the area of an inhabited farm (Wajda A. - unpubl. data).- - Grzęska b (!), 5005'02.6"N, 22 $27^{\prime} 09.5^{\prime \prime} \mathrm{E}$, $185 \mathrm{~m}$ a.s.1., one old shrub in the area of an inhabited farm (Wajda A. - unpubl. data). Rzeszów Foothills:-“Maćkówka (!), 50 $01^{\prime} 59.1^{\prime \prime} \mathrm{N}, 22^{\circ} 30^{\prime} 52.2^{\prime \prime} \mathrm{E}, 205 \mathrm{~m}$ a.s.1., one old shrub in the area of an inhabited farm (Wajda A. - unpubl. data).

OUTER WESTERN CARPATHIANS. Silesia Foothills:-“Ustroń - Nierodzim (!), 4946'19.3"N $18^{\circ} 47^{\prime} 59.4^{\prime \prime} \mathrm{E}$, $315 \mathrm{~m}$ a.s.l., one old (min. 100 years) shrub in the area of an inhabited farm (Knopek E. - unpubl. data).- ${ }^{*}$ Inwałd (!), $49^{\circ} 51^{\prime} 03.0^{\prime \prime} \mathrm{N}, 1^{\circ} 22^{\prime} 52.7^{\prime \prime} \mathrm{E}, 390 \mathrm{~m}$ a.s.1., one shrub of undefined age next to an abandoned wooden cottage (Chachuła P.

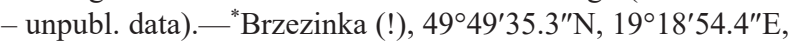
$420 \mathrm{~m}$ a.s.1., one shrub of undefined age in an old garden.- Jaworze (!), $49^{\circ} 47^{\prime} 42.5^{\prime \prime} \mathrm{N}, 18^{\circ} 55^{\prime} 27.3^{\prime \prime} \mathrm{E}, 370 \mathrm{~m}$ a.s.1., four old (min. 100 years) shrubs in the area of an inhabited farm (Czader B. - unpubl. data). Wiśnicz Foothills:- Łapczyca, $49^{\circ} 58^{\prime} 10.5^{\prime \prime} \mathrm{N}, 20^{\circ} 23^{\prime} 17.7^{\prime \prime} \mathrm{E}, 245 \mathrm{~m}$ a.s.1., 30 shoots in an oak-hornbeam forest (Chełmecki 2006).-Okocim, $49^{\circ} 55^{\prime} 40.0^{\prime \prime} \mathrm{N}, 20^{\circ} 38^{\prime} 08.3^{\prime \prime} \mathrm{E}, 335 \mathrm{~m}$ a.s.1., 50 shoots in an oak-hornbeam forest with an admixture of sycamore and ash and an unnaturally large proportion of beech (Pacyna 1969; Malik \& Nogawka 1999).-Faliszewice, 4952'21.9"N, $20^{\circ} 44^{\prime} 18.8^{\prime \prime} \mathrm{E}, 285 \mathrm{~m}$ a.s.l., about 110 shoots in a small patch of oak-hornbeam forest on the slopes of a ravine (Pacyna 

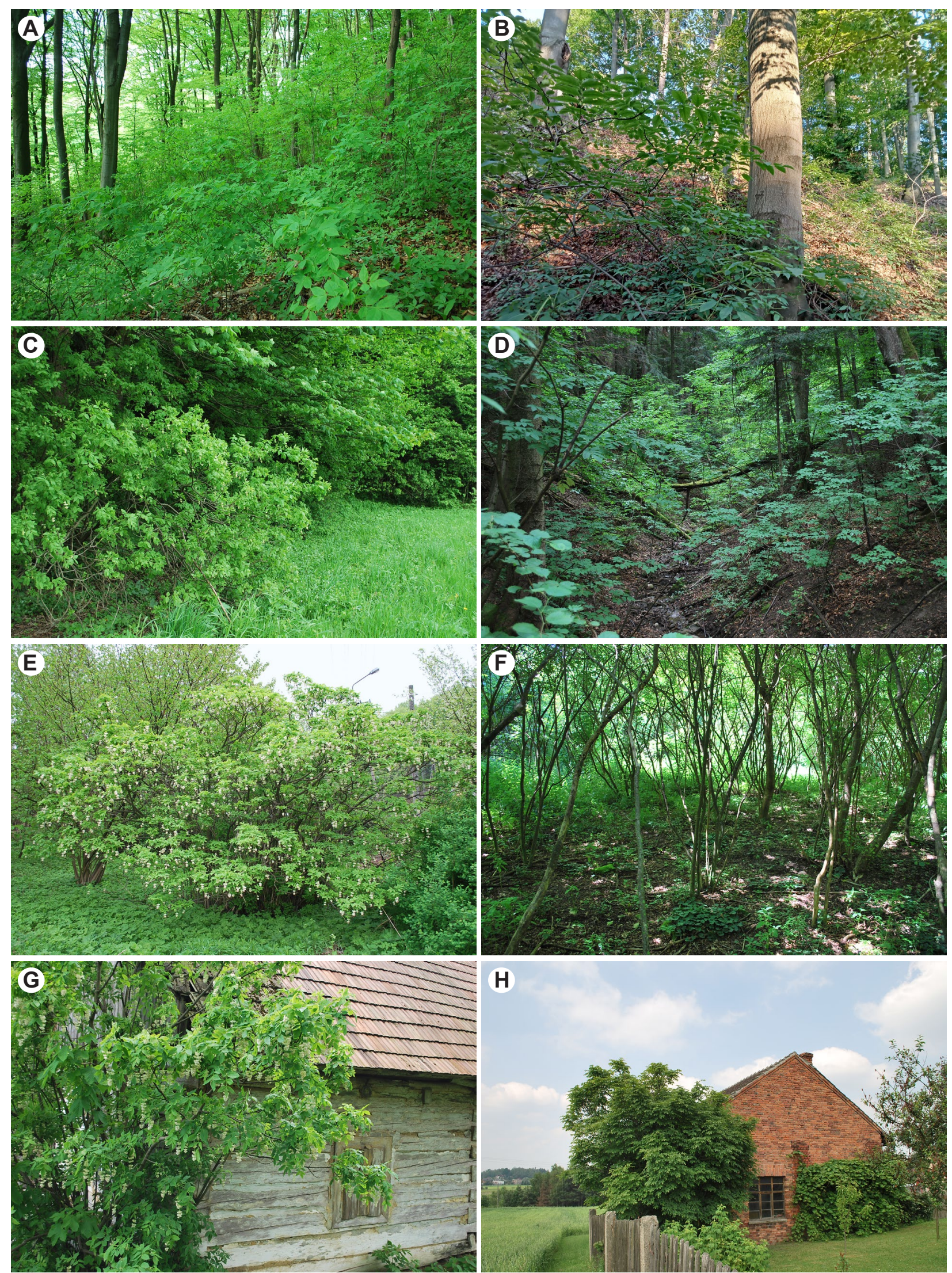

Figure 3. Examples of European bladdernut Staphylea pinnata sites in Poland. Sites considered as natural: A - Cisie a (Miechów Upland) on the slopes of a hill, near the edge of a beech - hornbeam forest; B - Baczyn (Tenczynek Hills) on limestone rock in an beech forest; C - Nowa Wieś (Low Beskid Mts) on a beech-hornbeam forest edge and in a steep slope; D - Mały Las (Low Beskid Mts) in an oak-hornbeam and beech forest, in the Magurski National Park area. Sites considered as an anthropogenic origin: E - Płaza (Tenczynek Hills) one old (min. 80 years) shrub in the place of a former building; F - Sołtysy (Eastern Roztocze) over a hundred large shoots in an oak-hornbeam forest on the ruins of the former Ukrainian village; G - Białowodzka Góra d (Wyspowy Beskid) one old shrub of undefined age, next to an abandoned house; $\mathrm{H}$ - Lyski (Rybnik Plateau) one min. 100-year-old shrub in the area of an inhabited farm. 
2004).-Zawada Lanckorońska, $49^{\circ} 52^{\prime} 15.5^{\prime \prime} \mathrm{N}, 20^{\circ} 47^{\prime} 31.2^{\prime \prime} \mathrm{E}$, $355 \mathrm{~m}$ a.s.1., two shoots on the Zawada Lanckorońska hillfort rampart in a beech forest (Suder 2014; Piechnik et al. 2020)."Mstów (!), 4947'24.1"N, $20^{\circ} 15^{\prime} 05.3^{\prime \prime}$ E, 335 m a.s.l., one old shrub of undefined age next to an abandoned wooden cottage (Zając-Zbrożek E. - unpubl. data). Żywiec Basin:"Radziechowy (!), 49³8'43.6"N, 1908'31.3"E, 410 m a.s.1., one old shrub of undefined age next to an inhabited house (Śliwka M. - unpubl. data). Mały Beskid Mts:- ${ }^{*}$ Zagórnik (!), $49^{\circ} 50^{\prime} 19.4^{\prime \prime} \mathrm{N}, 19^{\circ} 23^{\prime} 30.4^{\prime \prime} \mathrm{E}, 445 \mathrm{~m}$ a.s.1., one shrub on the ruins of a house (Chachuła P. - unpubl. data).- ${ }^{*}$ Rzyki - Pracica (!), 49 $46^{\prime} 35.9^{\prime \prime} \mathrm{N}, 19^{\circ} 23^{\prime} 29.9^{\prime \prime} \mathrm{E}, 645 \mathrm{~m}$ a.s.l., one old shrub of undefined age next to an abandoned wooden cottage (Zieliński J. - unpubl. data).- ${ }^{*}$ Targanice (!), 49 $47^{\prime} 14.1^{\prime \prime} \mathrm{N}, 19^{\circ} 19^{\prime} 21.1^{\prime \prime} \mathrm{E}$, $577 \mathrm{~m}$ a.s.l., one old shrub of undefined age next to an inhabited house (Chachuła P. - unpubl. data). Wyspowy Beskid:- 'Białowodzka Góra a (!), 4941'27.4"N , 20³7'51.4"E, 590 m a.s.1., one old shrub of undefined age, on the ruins of a house in a beech forest in a Nature Reserve area.—*Białowodzka Góra b (!), $49^{\circ} 41^{\prime} 39.1^{\prime \prime} \mathrm{N}, 20^{\circ} 37^{\prime} 58.7^{\prime \prime} \mathrm{E}, 415 \mathrm{~m}$ a.s.1., one old shrub of undefined age in a fence next to an inhabited wooden cottage.- ${ }^{*}$ Białowodzka Góra c (!), 4941'26.9" N, 20³8'52.1"E, $330 \mathrm{~m}$ a.s.1., one old shrub of undefined age, on the ruins of a house in an oak-hornbeam forest.—*Białowodzka Góra d (!), $49^{\circ} 41^{\prime} 10.1^{\prime \prime} \mathrm{N}, 20^{\circ} 38^{\prime} 37.2^{\prime \prime} \mathrm{E}, 290 \mathrm{~m}$ a.s.1., one old shrub of undefined age next to an abandoned house (Michalik A. - unpubl. data) (Fig. 3G).-Białowodzka Góra e, 4941'22.2" N, $20^{\circ} 38^{\prime} 40.9^{\prime \prime} \mathrm{E}, 345-365 \mathrm{~m}$ a.s.1., about 20 shoots in a small patch of oak-hornbeam forest over a small stream (Staszkiewicz \& Witkowski 1980; Staszkiewicz J. - unpubl. data).—-Zawadka, $49^{\circ} 41^{\prime} 04.7^{\prime \prime} \mathrm{N}, 20^{\circ} 37^{\prime} 26.7^{\prime \prime} \mathrm{E}, 540 \mathrm{~m}$ a.s.1., one old shrub of undefined age next to an inhabited house (Malik \& Nogawka

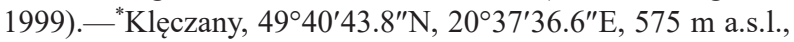
one old shrub of undefined age next to an inhabited house (Malik \& Nogawka 1999). Orawa-Jordanów Foothills:- ${ }^{*}$ Spytkowice (!), $49^{\circ} 34^{\prime} 21.3^{\prime \prime} \mathrm{N}, 19^{\circ} 48^{\prime} 07.3^{\prime \prime} \mathrm{E}, 560 \mathrm{~m}$ a.s.1., one 60 -year-old shrub in the area of an inhabited farm. Żywiec-Orawa Beskid Mts.:- ${ }^{*}$ Grojec a, $49^{\circ} 39^{\prime} 20.9^{\prime \prime} \mathrm{N}, 19^{\circ} 11^{\prime} 07.3^{\prime \prime} \mathrm{E}, 400 \mathrm{~m}$ a.s.l., one 80-year-old shrub next to an inhabited house (Nowak 2012).- - Grojec b, 49 $39^{\prime} 30.0^{\prime \prime} \mathrm{N}, 19^{\circ} 10^{\prime} 56.1^{\prime \prime} \mathrm{E}, 380 \mathrm{~m}$ a.s.1., one 50-year-old shrub in the area of an inhabited farm (Nowak 2012; Żur M. - unpubl. data).- ${ }^{*} P e w e l$ Wielka - Wyczyszczon a (!), $49^{\circ} 40^{\prime} 36.3^{\prime \prime} \mathrm{N}, 19^{\circ} 24^{\prime} 29.8^{\prime \prime} \mathrm{E}, 665 \mathrm{~m}$ a.s.l., one old shrub of undefined age next to inhabited house (Trybała M. - unpubl. data).- Pewel Wielka - Wyczyszczon b (!), 4940'32.5" $\mathrm{N}$, $19^{\circ} 24^{\prime} 22.5^{\prime \prime} \mathrm{E}, 690 \mathrm{~m}$ a.s.l., one old shrub of undefined age next to an inhabited house (Trybała M. - unpubl. data).- ${ }^{*}$ Skawica - Patoroczna (!), 49॰38'28.9"N, 19³8'58.1"E, 805 m a.s.l.,one old shrub (min. 80 years) in a mountain clearing with one inhabited wooden cottage. Sącz Beskid Mts.:- ${ }^{*}$ Makowica (!), $49^{\circ} 29^{\prime} 57.1^{\prime \prime} \mathrm{N}, 20^{\circ} 42^{\prime} 18.2^{\prime \prime} \mathrm{E}, 835 \mathrm{~m}$ a.s.1., one old shrub on a stone pile in a mountain clearing near a beech forest edge. Origin and age unknown (Zelek 2019).- - ${ }^{*}$ Labowiec (!), $49^{\circ} 30^{\prime} 41.2^{\prime \prime} \mathrm{N}, 20^{\circ} 50^{\prime} 43.6^{\prime \prime} \mathrm{E}, 525-530 \mathrm{~m}$ a.s.l., five 80 -year-old shrubs in the area of an old, inhabited farm (Widlak M. - unpubl. data). Rożnów Foothills:-Las Kurowski (!), 4941'45.9"N, $20^{\circ} 40^{\prime} 37.3^{\prime \prime} \mathrm{E}, 385 \mathrm{~m}$ a.s.l., about 20 shoots in a beech forest (Michalik A. - unpubl. data).-Ostrysz, 49 46'23.6"N, $20^{\circ} 47^{\prime} 39.3^{\prime \prime} \mathrm{E}, 415 \mathrm{~m}$ a.s.l., two clusters of shoots in a beech forest on the slope of a former landslide and below the base of the sandstone rock (Kucharzyk 1991; Piechnik et al. 2020).Pławna, 494 $44^{\prime} 44.9^{\prime \prime} \mathrm{N}, 20^{\circ} 56^{\prime} 24.6^{\prime \prime} \mathrm{E}, 265-275 \mathrm{~m}$ a.s.1., about 200 shoots in an oak-hornbeam forest on the steep bank of the Biała Tarnowska River (Piechnik et al. 2020). - ${ }^{*} Z$ donia (!), $49^{\circ} 49^{\prime} 45.0^{\prime \prime} \mathrm{N}, 20^{\circ} 48^{\prime} 03.1^{\prime \prime} \mathrm{E}, 330 \mathrm{~m}$ a.s.l., one several decades-old shrub and three several years old shrubs on the ruins of a wooden house in a young birch forest.- ${ }^{*}$ Ruda Kameralna (!), $49^{\circ} 49^{\prime} 09.5^{\prime \prime} \mathrm{N}, 20^{\circ} 43^{\prime} 22.8^{\prime \prime} \mathrm{E}, 325 \mathrm{~m}$ a.s.l., one at least 80 -year-old shrub near to an inhabited wooden house.- - Chodorowa (!), 49³9'25.2"N, 2054'25.9"E, $319 \mathrm{~m}$ a.s.l., one several decades-old shrub next to an inhabited old house. Ciężkowice Foothills:-Góra Świętego Marcina a, $49^{\circ} 59^{\prime} 21.1^{\prime \prime} \mathrm{N}, 21^{\circ} 00^{\prime} 13.3^{\prime \prime} \mathrm{E}, 305 \mathrm{~m}$ a.s.1., 10 shoots in an oak-hornbeam forest with an unnaturally large proportion of beech (Grzegorzek 1853; Heger 1871; Gostyńska 1961; Piątek M. - unpubl. data).-Góra Świętego Marcina b (!), $49^{\circ} 59^{\prime} 16.4^{\prime \prime} \mathrm{N}, 21^{\circ} 00^{\prime} 18.9^{\prime \prime} \mathrm{E}, 328 \mathrm{~m}$ a.s.l., one shrub on the hillfort rampart in a beech forest.-Piotrkowice (!), 49 $56^{\prime} 17.1^{\prime \prime} \mathrm{N}$, $20^{\circ} 59^{\prime} 27.5^{\prime \prime} \mathrm{E}, 365 \mathrm{~m}$ a.s.1., about 40 shoots in beech forest.Piotrkowice - Żydowski Las (!), 49 $56^{\prime} 28.5^{\prime \prime} \mathrm{N}, 20^{\circ} 58^{\prime} 28.3^{\prime \prime} \mathrm{E}$, $330 \mathrm{~m}$ a.s.l., about 30 shoots in a young beech forest.Tuchowski Las a (!), 49 $54^{\prime} 55.5^{\prime \prime} \mathrm{N}, 21^{\circ} 04^{\prime} 39.2^{\prime \prime} \mathrm{E}, 280 \mathrm{~m}$ a.s.1., 5 shoots in a fir forest (Kauzal P. - unpubl. data).-Tuchowski Las b, 49 $54^{\prime} 49.3^{\prime \prime} \mathrm{N}, 21^{\circ} 04^{\prime} 47.7^{\prime \prime} \mathrm{E}, 300-330 \mathrm{~m}$ a.s.1., about 100 shoots in an oak-hornbeam forest on the west slope of the ravine (Towpasz \& Stachurska-Swakoń 2015, Kauzal P. - unpubl. data), previously reported as 'Karwodrza' (Kornaś \& Wróbel 1972).-Tuchowski Las c, 4954'27.7"N, $21^{\circ} 05^{\prime} 03.3^{\prime \prime} \mathrm{E}, 315 \mathrm{~m}$ a.s.l., over a dozen shoots dispersed in the slopes of a ravine in an oak-beech-fir forest (Towpasz \& Stachurska-Swakoń 2015, Kauzal P. - unpubl. data).-Tuchowski Las d, $49^{\circ} 54^{\prime} 22.0^{\prime \prime} \mathrm{N}, 21^{\circ} 05^{\prime} 37.9^{\prime \prime} \mathrm{E}, 310-330 \mathrm{~m}$ a.s.1., about 40 shoots in beech-fir-oak forest (Bajda 2009).-Ś Świniogóra Szynwałdzka a, $49^{\circ} 56^{\prime} 29.5^{\prime \prime} \mathrm{N}, 21^{\circ} 09^{\prime} 36.5^{\prime \prime} \mathrm{E}, 385 \mathrm{~m}$ a.s.1., 70 shoots growing over the edges of a small landslide in a beech forest (Piechnik et al. 2020).-Świniogóra Szynwałdzka b, $49^{\circ} 56^{\prime} 38.7^{\prime \prime} \mathrm{N}, 21^{\circ} 09^{\prime} 58.5^{\prime \prime} \mathrm{E}, 290 \mathrm{~m}$ a.s.1., about 20 shoots growing in a clearing in a beech-fir forest between the forest road and the valley of a small stream (Piechnik et al. 2020).Góra Kokocz, $49^{\circ} 55^{\prime} 48.9^{\prime \prime} \mathrm{N}, 2^{\circ} 12^{\prime} 42.0^{\prime \prime} \mathrm{E}, 370-390 \mathrm{~m}$ a.s.1., about 120 shoots in the $\mathrm{N}$ slope of the Kokocz Mountain, dispersed over a distance of $500 \mathrm{~m}$, in an oak-hornbeam forest (Towpasz 2011; Towpasz \& Stachurska-Swakoń 2015; Kauzal P. - unpubl. data).—Joniny - Kosówka (!), 4953'42.7"N, $21^{\circ} 10^{\prime} 31.3^{\prime \prime} \mathrm{E}, 320 \mathrm{~m}$ a.s.1., two small clusters of shoots in an oak-hornbeam-fir forest (Rutana J. - unpubl. data).- - Joniny Szubienice (!), $49^{\circ} 53^{\prime} 41.6^{\prime \prime} \mathrm{N}, 21^{\circ} 10^{\prime} 48.3^{\prime \prime} \mathrm{E}, 315 \mathrm{~m}$ a.s.l., few shoots in a hornbeam forest (Rutana J. - unpubl. data).-Ryglice - Bukowina, 49 $\left.53^{\prime} 42.2^{\prime \prime} \mathrm{N}, 21^{\circ} 08^{\prime} 53.6^{\prime \prime} \mathrm{E}\right] .300 \mathrm{~m}$ a.s.l., about 3,000 shoots on the steep slopes of ravines in an oak-beechhornbeam forest (Kozik \& Nabożny 1999).-Berdechów (!), $49^{\circ} 49^{\prime} 21.4^{\prime \prime} \mathrm{N}, 20^{\circ} 58^{\prime} 18.2^{\prime \prime} \mathrm{E}, 310 \mathrm{~m}$ a.s.l., a few shoots in beech-fir forest on the ravine slope (Fitowicz J. - unpubl. data).-Tursko (!), 49 $48^{\prime} 41.4^{\prime \prime} \mathrm{N}, 20^{\circ} 59^{\prime} 08.8^{\prime \prime} \mathrm{E}, 315 \mathrm{~m}$ a.s.1., two clusters of shoots in beech-fir forest on the ravine slopes (Fitowicz J. - unpubl. data).-Lubaszowa, 49 $50^{\prime} 39.8^{\prime \prime} \mathrm{N}$, $21^{\circ} 01^{\prime} 29.8^{\prime \prime} \mathrm{E}, 325 \mathrm{~m}$ a.s.l., about 20 shoots in a beech-fir forest on the ravine slopes (Ociepa A. M. - unpubl. data), previously reported as 'Między Jodłówką Tuchowską a Siedliskami' (Kornaś \& Wróbel 1972).-Zborowice, 4945'10.4"N, $20^{\circ} 57^{\prime} 03.0^{\prime \prime} \mathrm{E}, 270 \mathrm{~m}$ a.s.1., in an oak-hornbeam forest, about 40 shoots on the steep slope of a hill close to the Ciężkowice-Grybów road (Kucharzyk 1991), previously reported as 'Pławna' (Kornaś \& Wróbel 1972). - Jodłowa - Rynek (!), $49^{\circ} 52^{\prime} 18.2^{\prime \prime} \mathrm{N}, 21^{\circ} 18^{\prime} 37.0^{\prime \prime} \mathrm{E}, 300 \mathrm{~m}$ a.s.l., one shrub in an oak-hornbeam forest (Piątek K. - unpubl. data).—Jodłówka Tuchowska (!), 49 $50^{\prime} 37.4^{\prime \prime} \mathrm{N}, 21^{\circ} 05^{\prime} 54.9^{\prime \prime} \mathrm{E}, 497 \mathrm{~m}$ a.s.1., one shrub by the forest road to Brzanka Mountain (Piątek K. - unpubl. data).-Dęborzyn, $49^{\circ} 54^{\prime} 48.9^{\prime \prime} \mathrm{N}, 21^{\circ} 19^{\prime} 40.0^{\prime \prime} \mathrm{E}, 240$ $310 \mathrm{~m}$ a.s.1., about 1,000 shoots in a beech forest (Kornaś \& Wróbel 1972; Kornaś et al. 1996; Piątek 2007). Strzyżów Foothills:-Podgrodzie, $50^{\circ} 00^{\prime} 26.1^{\prime \prime} \mathrm{N}, 21^{\circ} 21^{\prime} 46.8^{\prime \prime} \mathrm{E}, 300 \mathrm{~m}$ 
a.s.1., a few shoots in oak-hornbeam forest (Towpasz 2019).Budzisz a, $50^{\circ} 01^{\prime} 38.9^{\prime \prime} \mathrm{N}, 21^{\circ} 26^{\prime} 43.5^{\prime \prime} \mathrm{E}, 290 \mathrm{~m}$ a.s.l., about 200 shoots on the E slope of the ravine, in an oak-hornbeam and beech forest (Towpasz 1987). - Budzisz b, $50^{\circ} 01^{\prime} 36.9^{\prime \prime} \mathrm{N}$, $21^{\circ} 26^{\prime} 51.7^{\prime \prime} \mathrm{E}, 305 \mathrm{~m}$ a.s.l., about 80 shoots in a small gap in a beech forest within a small landslide (Towpasz 1987) (Fig. 3B).- Gawrzyłowa a, $50^{\circ} 02^{\prime} 14.6^{\prime \prime} \mathrm{N}, 21^{\circ} 27^{\prime} 30.9^{\prime \prime} \mathrm{E}, 285 \mathrm{~m}$ a.s.l., about 30 shoots near the forest edge in a beech forest (Oklejewicz et al. 2008; FMP Strzyżów 2013).-Gawrzyłowa b, $50^{\circ} 01^{\prime} 58.7^{\prime \prime} \mathrm{N}, 21^{\circ} 27^{\prime} 31.7^{\prime \prime} \mathrm{E}, 320 \mathrm{~m}$ a.s.1., about 100 shoots in a beech forest on the slopes of the ravine within a small landslide from a few years ago (Oklejewicz et al. 2008; FMP Strzyżów

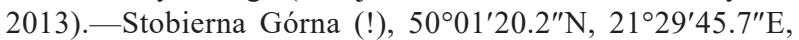
$350 \mathrm{~m}$ a.s.1., 20 shots on a gentle slope in a beech forest (Trzeciak A. - unpubl. data). - Budy Łopuchowskie (!), 50 $01^{\prime} 55.5^{\prime \prime} \mathrm{N}$, $21^{\circ} 30^{\prime} 47.8^{\prime \prime} \mathrm{E}, 330 \mathrm{~m}$ a.s.l., about 100 shoots on the slopes of the ravine in a beech forest (FMP Strzyżów 2013).-Braciejowa, $49^{\circ} 59^{\prime} 14.2^{\prime \prime} \mathrm{N}, 21^{\circ} 27^{\prime} 46.5^{\prime \prime} \mathrm{E}, 375 \mathrm{~m}$ a.s.1., about 200 shoots on the slopes and on the former hillfort in a beech forest (Towpasz 1987; Suder 2014).-_Januszkowice a (!), 4950'55.2"N, $21^{\circ} 26^{\prime} 12.2^{\prime \prime} \mathrm{E}, 295-300 \mathrm{~m}$ a.s.1., about 200 shrubs on a ravine slopes in a beech-fir forest.-Januszkowice b (!), 49 $51^{\prime} 00.2^{\prime \prime} \mathrm{N}$, $21^{\circ} 26^{\prime} 12.6^{\prime \prime} \mathrm{E}, 275 \mathrm{~m}$ a.s.1., one 3-meter-tall shrub growing on the bottom of the ravine, near a small watercourse, in an alder-ash forest.-Podzamcze a, 49 $46^{\prime} 27.7^{\prime \prime} \mathrm{N}, 21^{\circ} 27^{\prime} 22.1^{\prime \prime} \mathrm{E}$, $260 \mathrm{~m}$ a.s.1., several dozen shoots in two clusters on the steep slopes of the ravine in an oak-fir forest (FMP Kołaczyce

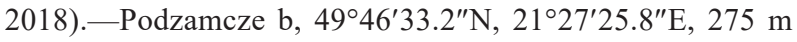
a.s.l., several dozen shoots in two clusters on the steep slopes of the ravine in an oak-fir forest (FMP Kołaczyce 2018).Lubzina - Góry, $50^{\circ} 02^{\prime} 59.0^{\prime \prime} \mathrm{N}, 21^{\circ} 30^{\prime} 03.3^{\prime \prime} \mathrm{E}, 290 \mathrm{~m}$ a.s.l., two shrubs at the edge of the water exudate in a beech-larch forest. Origin unknown (FMP Strzyżów 2013).--Las Kamieniec, $49^{\circ} 58^{\prime} 38.1^{\prime \prime} \mathrm{N}, 21^{\circ} 40^{\prime} 48.6^{\prime \prime} \mathrm{E}, 400 \mathrm{~m}$ a.s.1., several dozen shoots in an oak forest. Site was previously reported as 'Zagorzyce' (Towpasz 1987, FMP Strzyżów 2013).-Wola Zgłobieńska a, $49^{\circ} 58^{\prime} 08.9^{\prime \prime} \mathrm{N}, 21^{\circ} 46^{\prime} 43.8^{\prime \prime} \mathrm{E}, 380 \mathrm{~m}$ a.s.l., several dozen shoots in a larch-beech forest (Gostyńska 1961, FMP Strzyżów

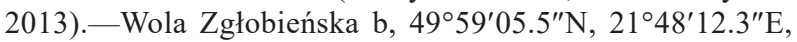
$310 \mathrm{~m}$ a.s.l., several hundred shoots forming a dense layer of undergrowth on a gentle slope. In a pine forest in an oak-hornbeam habitat (Gostyńska 1961; FMP Strzyżów 2013).-Wola Zgłobieńska c, $49^{\circ} 59^{\prime} 08.9^{\prime \prime} \mathrm{N}, 21^{\circ} 46^{\prime} 34.4^{\prime \prime} \mathrm{E}, 320 \mathrm{~m}$ a.s.1., about 50 shoots on a gentle slope. In a beech forest in an oak-hornbeam habitat (Gostyńska 1961; FMP Strzyżów 2013).--Las Niechobrz (!), $49^{\circ} 58^{\prime} 12.3^{\prime \prime} \mathrm{N}, 21^{\circ} 50^{\prime} 05.7^{\prime \prime} \mathrm{E}, 370 \mathrm{~m}$ a.s.l., several dozen shoots in three clusters in a beech forest (Łuczaj Ł. - unpubl. data).-Wąwóz Ratośniówki, 4952'45.5”N, 2147'22.1"E, 305-320 m a.s.1., about 90 shoots on the banks of the main ravine, less frequently in its side branches, in an oak-hornbeam forest (Gostyńska 1961; Wójcik 2012).——ętownia, $49^{\circ} 53^{\prime} 10.7^{\prime \prime} \mathrm{N}, 21^{\circ} 46^{\prime} 18.5^{\prime \prime} \mathrm{E}, 310 \mathrm{~m}$ a.s.1., about 70 shoots on the steep slope of the ravine, in a beech forest with sycamore, fir and hornbeam (Browicz 1959; Gostyńska 1961; Wójcik T.

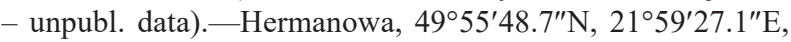
$380 \mathrm{~m}$ a.s.1., about 200 shoots in a thermophilic beech forest (Gutkowska et al. 2002).-Kamera a, $49^{\circ} 54^{\prime} 24.2^{\prime \prime} \mathrm{N}$, $21^{\circ} 26^{\prime} 28.5^{\prime \prime} \mathrm{E}, 385 \mathrm{~m}$ a.s.1., about 370 shoots in a beech forest in a Nature Reserve area (Gostyńska 1961; Ochał 2009).-Kamera b, 49 $54^{\prime} 24.2^{\prime \prime} \mathrm{N}, 21^{\circ} 26^{\prime} 28.5^{\prime \prime} \mathrm{E}, 390 \mathrm{~m}$ a.s.1., about 450 shoots in a fir forest in a Nature Reserve area (Gostyńska 1961; Ochał 2009). Dynów Foothills:-Cierpisz (!), $50^{\circ} 00^{\prime} 36.3^{\prime \prime} \mathrm{N}, 22^{\circ} 10^{\prime} 08.9^{\prime \prime} \mathrm{E}, 340 \mathrm{~m}$ a.s.1., one old shrub of undefined origin and age near the ravine in a pine-beech forest, probably previously reported as 'Kraczkowa' (Oklejewicz et al.

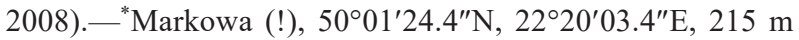

a.s.l., one old shrub of undefined age next to an abandoned house (Olbrycht T. - unpubl. data).-Podlas a, 49 $58^{\prime} 09.5^{\prime \prime} \mathrm{N}$, $22^{\circ} 14^{\prime} 40.5^{\prime \prime} \mathrm{E}, 380 \mathrm{~m}$ a.s.1., about 60 shoots in an oak-hornbeambirch forest (Gutkowska et al. 2002; FMP Kańczuga 2013).Podlas b, $49^{\circ} 58^{\prime} 03.0^{\prime \prime} \mathrm{N}, 22^{\circ} 14^{\prime} 29.5^{\prime \prime} \mathrm{E}, 395 \mathrm{~m}$ a.s.l., about 35 shoots in a fir-larch forest (Gutkowska et al. 2002; FMP Kańczuga 2013).—Podlas c, $49^{\circ} 57^{\prime} 55.2^{\prime \prime} \mathrm{N}, 22^{\circ} 15^{\prime} 21.1^{\prime \prime} \mathrm{E}$, $380 \mathrm{~m}$ a.s.l., over a dozen shoots in a beech-sycamore forest (Gutkowska et al. 2002; FMP Kańczuga 2013)._Lipnik, $49^{\circ} 59^{\prime} 20.4^{\prime \prime} \mathrm{N}, 22^{\circ} 18^{\prime} 43.9^{\prime \prime} \mathrm{E}, 305-315 \mathrm{~m}$ a.s.1., about 40 shoots in three clusters on a plateau near the eastern edge of the small ravine in an oak-hornbeam forest with beech and ash admixture (Oklejewicz et. al. 2008; Olbrycht T. - unpubl. data).--Husówka a, $49^{\circ} 57^{\prime} 59.3^{\prime \prime} \mathrm{N}, 22^{\circ} 18^{\prime} 53.2^{\prime \prime} \mathrm{E}, 375 \mathrm{~m}$ a.s.1., about 400 shoots in an oak-hornbeam forest especially in a forest edge near road in a Nature Reserve area (Głowacka et al. 1996; Burghardt 2012; FMP Kańczuga 2013).-Husówka b, 4957'50.6”N, $22^{\circ} 18^{\prime} 56.5^{\prime \prime} \mathrm{E}, 350-370 \mathrm{~m}$ a.s.1., about 100 shoots along the ravine in an oak-hornbeam forest in a Nature Reserve area (Głowacka et al. 1996; Burghardt 2012; FMP Kańczuga 2013).--Husówka c, $49^{\circ} 57^{\prime} 25.8^{\prime \prime} \mathrm{N}, 22^{\circ} 18^{\prime} 44.9^{\prime \prime} \mathrm{E}, 340 \mathrm{~m}$ a.s.1. about 250 shoots in an oak-hornbeam forest in a Nature Reserve area (Głowacka et al. 1996; Burghardt 2012; FMP Kańczuga 2013).- - Nieważka a (!), 49 $56^{\prime} 48.3^{\prime \prime} \mathrm{N}, 22^{\circ} 20^{\prime} 08.2^{\prime \prime} \mathrm{E}, 305 \mathrm{~m}$ a.s.l., one young shrub near an abandoned farm (Krzeszewski M. - unpubl. data).- - Nieważka b (!), 49 $56^{\prime} 37.7^{\prime \prime} \mathrm{N}, 22^{\circ} 20^{\prime} 08.0^{\prime \prime} \mathrm{E}$, $305 \mathrm{~m}$ a.s.l., one old shrub of undefined age next to an abandoned house (Krzeszewski M. - unpubl. data).--Nieważka c (!), $49^{\circ} 56^{\prime} 42.0^{\prime \prime} \mathrm{N}, 22^{\circ} 19^{\prime} 57.4^{\prime \prime} \mathrm{E}, 280 \mathrm{~m}$ a.s.1., one old shrub of undefined age next to an abandoned house (Krzeszewski M. - unpubl. data).- - Nieważka d (!), $49^{\circ} 56^{\prime} 45.0^{\prime \prime} \mathrm{N}, 22^{\circ} 19^{\prime} 56.3^{\prime \prime} \mathrm{E}$, $280 \mathrm{~m}$ a.s.1., one old shrub of undefined age next to an abandoned house (Krzeszewski M. - unpubl. data).-Świtałówka, $49^{\circ} 54^{\prime} 46.4^{\prime \prime} \mathrm{N}, 22^{\circ} 21^{\prime} 37.2^{\prime \prime} \mathrm{E}, 375 \mathrm{~m}$ a.s.1., about 30 shoots on a gentle slope in a beech forest (Oklejewicz et al. 2008; FMP Kańczuga 2013) previously reported as 'koło wsi Łopuszka Wielka i Widne' (Gostyńska 1961) or 'Łopuszka Wielka Górka' (Jaźwa \& Stadnicka-Futoma 2014).-Kramarzówka, $49^{\circ} 52^{\prime} 33.0^{\prime \prime} \mathrm{N}, 22^{\circ} 27^{\prime} 41.3^{\prime \prime} \mathrm{E}, 375 \mathrm{~m}$ a.s.l., about 70 shoots dispersed on a partially exposed gentle slope in a fir forest (Gutkowska et al. 2002; FMP Kańczuga 2013).—Góra Borusz a, $49^{\circ} 51^{\prime} 46.8^{\prime \prime} \mathrm{N}, 22^{\circ} 36^{\prime} 22.4^{\prime \prime} \mathrm{E}, 385 \mathrm{~m}$ a.s.1., about 80 shoots on an exposed flat area with a canopy of trees consisting of single ashes, maples, hornbeams and Scots pines. Previously reported as 'Góra Borucz' (Deptuch et al. 1998; FMP Kańczuga 2013).Góra Borusz b, 49 $51^{\prime} 42.1^{\prime \prime} \mathrm{N}, 22^{\circ} 36^{\prime} 13.1^{\prime \prime} \mathrm{E}, 365 \mathrm{~m}$ a.s.l., about 150 shoots on an exposed flat area with a canopy of trees consisting of single ashes, maples, hornbeams and Scots pines. Previously reported as 'Góra Borucz' (Deptuch et al. 1998; FMP

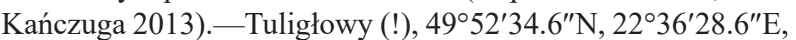
$365 \mathrm{~m}$ a.s.l., over a dozen shoots in a beech-oak forest.-Wola Węgierska, $49^{\circ} 51^{\prime} 51.6^{\prime \prime} \mathrm{N}, 22^{\circ} 34^{\prime} 42.9^{\prime \prime} \mathrm{E}, 285 \mathrm{~m}$ a.s.l., about 60 shoots in an oak-hornbeam forest (Gutkowska et al. 2002; Kucharzyk S. - unpubl. data).-Rokietnica, 49 52'48.7"N, $22^{\circ} 37^{\prime} 38.1^{\prime \prime} \mathrm{E}, 315 \mathrm{~m}$ a.s.1., a few shoots on slightly sloping terrain, that has been partially exposed, under the canopy of larch and sycamore trees, in an oak-hornbeam forest (Krzaczek \& Krzaczek 1983; FMP Kańczuga 2013).-Wola Rokietnicka - Zawarcie, $49^{\circ} 52^{\prime} 05.2^{\prime \prime} \mathrm{N}, 22^{\circ} 39^{\prime} 17.3^{\prime \prime} \mathrm{E}, 315 \mathrm{~m}$ a.s.l., over a dozen shrubs in an oak-hornbeam forest. Previously reported as 'Zawarcie, leśnictwo Bełwin' (Oklejewicz et al. 2008; FMP Krasiczyn 2018).-Wołosówka a (!), 4950'44.5"N, $22^{\circ} 41^{\prime} 13.9^{\prime \prime} \mathrm{E}, 340 \mathrm{~m}$ a.s.1., about 40 shoots in a beech-oak forest (FMP Krasiczyn 2018). Krasiczyn 36 d-Wołosówka b (!), $49^{\circ} 50^{\prime} 46.4^{\prime \prime} \mathrm{N}, 22^{\circ} 41^{\prime} 19.9^{\prime \prime} \mathrm{E}, 340 \mathrm{~m}$ a.s.l., about 30 shoots in an oak forest (FMP Krasiczyn 2018). - Łętownia (Łazy) a, 
$49^{\circ} 49^{\prime} 45.2^{\prime \prime} \mathrm{N}, 22^{\circ} 42^{\prime} 11.4^{\prime \prime} \mathrm{E}, 330 \mathrm{~m}$ a.s.1., about 100 shoots in a sycamore-beech forest (FMP Krasiczyn 2018). - Lętownia (Łazy) b, 49 $49^{\prime} 42.0^{\prime \prime} \mathrm{N}, 22^{\circ} 42^{\prime} 24.6^{\prime \prime} \mathrm{E}, 330 \mathrm{~m}$ a.s.1., about 200 shoots in a beech-hornbeam forest (FMP Krasiczyn 2018).Fort Bruner, $49^{\circ} 49^{\prime} 33.5^{\prime \prime} \mathrm{N}, 22^{\circ} 43^{\prime} 25.7^{\prime \prime} \mathrm{E}, 335 \mathrm{~m}$ a.s.l., about 150 shoots in a beech-oak forest (Kotula 1881; Wilk 2004).Przemyśl - Lipowica, 4948'37.7"N, 2245'23.2"E, 330 m a.s.1., about 200 shoots in an oak-hornbeam forest.-Średnia na Dziale, $49^{\circ} 49^{\prime} 36.1^{\prime \prime} \mathrm{N}, 22^{\circ} 35^{\prime} 46.7^{\prime \prime} \mathrm{E}, 405 \mathrm{~m}$ a.s.l., about 5 shoots in a beech forest. Previously reported as 'leśnictwo Bełwin' (Oklejewicz et al. 2008; FMP Krasiczyn 2018).-Dolina Hołubli a, $49^{\circ} 49^{\prime} 20.4^{\prime \prime} \mathrm{N}, 22^{\circ} 37^{\prime} 06.7^{\prime \prime} \mathrm{E}, 340 \mathrm{~m}$ a.s.1., about 40 shoots in a beech forest (FMP Krasiczyn 2018).-Dolina Hołubli b, $49^{\circ} 49^{\prime} 30.2^{\prime \prime} \mathrm{N}, 22^{\circ} 37^{\prime} 26.9^{\prime \prime} \mathrm{E}, 360 \mathrm{~m}$ a.s.1., about 50 shoots in a beech forest (FMP Krasiczyn 2018).-Dolina Hołubli c, $49^{\circ} 49^{\prime} 12.5^{\prime \prime} \mathrm{N}, 22^{\circ} 37^{\prime} 39.9^{\prime \prime} \mathrm{E}, 345 \mathrm{~m}$ a.s.l., about 90 shoots in a beech forest in a Nature Reserve area (FMP Krasiczyn 2018). -Dolina Hołubli d, 4948'57.6"N, 22 37'32.3"E, $280 \mathrm{~m}$ a.s.1., about 30 shoots in a beech forest in a Nature Reserve area (FMP Krasiczyn 2018). All sites from Dolina Hołubli were previously reported as 'Hołubla' (Kornaś \& Wróbel 1972). - Las Rokitny (!), $49^{\circ} 48^{\prime} 52.0^{\prime \prime} \mathrm{N}, 21^{\circ} 58^{\prime} 30.0^{\prime \prime} \mathrm{E}, 410 \mathrm{~m}$ a.s.l., over a dozen shoots near forest road in a fir forest (FMP Strzyżow 2013).-Czerwonki Hermanowskie (!), 4954'18.8"N, $22^{\circ} 01^{\prime} 42.7^{\prime \prime} \mathrm{E}, 365 \mathrm{~m}$ a.s.1., 10 shoots in a beech forest (FMP Strzyżów 2013).—Zamkowy Las (!), 4956'00.0"N, $21^{\circ} 49^{\prime} 41.0^{\prime \prime} \mathrm{E}, 270 \mathrm{~m}$ a.s.1., 3-5 shoots on a steep slope in an oak-hornbeam forest (Kucharzyk S. - unpubl. data).-Wyżne

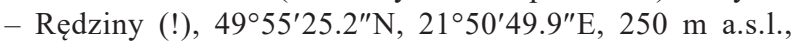
25 shoots in a pine-beech forest (FMP Strzyżów 2013).Humniska, $49^{\circ} 41^{\prime} 46.0^{\prime \prime} \mathrm{N}, 22^{\circ} 04^{\prime} 18.2^{\prime \prime} \mathrm{E}, 390 \mathrm{~m}$ a.s.1., about 45 shoots in a beech-hornbeam forest (FMP Brzozów 2017).Czarna Góra a, $49^{\circ} 41^{\prime} 32.0^{\prime \prime} \mathrm{N}, 22^{\circ} 05^{\prime} 00.9^{\prime \prime} \mathrm{E}, 450 \mathrm{~m}$ a.s.1., about 80 shoots in a fir-oak forest (FMP Brzozów 2017). - Czarna Góra b, 49 $41^{\prime} 34.0^{\prime \prime} \mathrm{N}, 22^{\circ} 05^{\prime} 05.4^{\prime \prime} \mathrm{E}, 430 \mathrm{~m}$ a.s.l., about 10 shoots in a birch-beech forest (FMP Brzozów 2017). - Czarna Góra c, $49^{\circ} 41^{\prime} 34.8^{\prime \prime} \mathrm{N}, 22^{\circ} 05^{\prime} 10.9^{\prime \prime} \mathrm{E}, 420 \mathrm{~m}$ a.s.1., about 15 shoots in a birch-beech forest (FMP Brzozów 2017). - Czarna

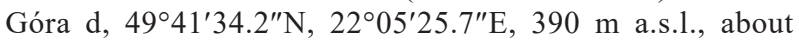
50 shoots in small gap in a beech forest (FMP Brzozów 2017; Olszowska 2019). All sites from Czarna Góra and Humniska were previously reported as "na NE od Humnisk, nad przysiółkiem Łazy’ (Bober 1974).-Góra Kukoczkowa, $49^{\circ} 41^{\prime} 23.7^{\prime \prime} \mathrm{N}, 21^{\circ} 58^{\prime} 34.5^{\prime \prime} \mathrm{E}, 380 \mathrm{~m}$ n.p.m., about 50 shoots in a beech forest with fir-sycamore admixture (Gostyńska 1961; FMP Brzozów 2017; Olszowska 2019).—Przysietnica (!), $49^{\circ} 43^{\prime} 06.6^{\prime \prime} \mathrm{N}, 22^{\circ} 03^{\prime} 05.9^{\prime \prime} \mathrm{E}, 300 \mathrm{~m}$ a.s.l., one old shrub in the bushes on the outskirts of the village.-Grabownica, $49^{\circ} 38^{\prime} 15.6^{\prime \prime} \mathrm{N}, 22^{\circ} 01^{\prime} 01.1^{\prime \prime} \mathrm{E}, 360 \mathrm{~m}$ n.p.m., about 25 shoots in a beech forest (Bober 1974; FMP Brzozów 2017).—Trześniów - Bukowskie Góry (!), 49³9'15.7"N, 21 ${ }^{\circ} 57^{\prime} 06.2^{\prime \prime} \mathrm{E}, 350 \mathrm{~m}$ n.p.m., about 40 shoots in a beech-fir forest (FMP Brzozów

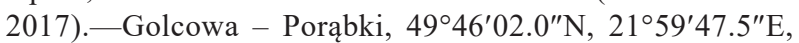
$320 \mathrm{~m}$ a.s.l., about 40 shoots in an alder-ash forest. Previously reported as 'Przysietnica 107A' (Gostyńska 1961).—- Obarzym

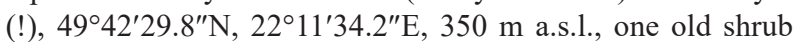
near wooden building in the inhabited farm.-Niewistka, $49^{\circ} 43^{\prime} 55.2^{\prime \prime} \mathrm{N}, 22^{\circ} 11^{\prime} 12.2^{\prime \prime} \mathrm{E}, 420 \mathrm{~m}$ n.p.m., about 35 shoots in a fir forest, previously reported as 'Rzeki' (Gutkowska \& Niedźwiecka 2016; FMP Brzozów 2017).-Góra Wroczeń, $49^{\circ} 37^{\prime} 34.9^{\prime \prime} \mathrm{N}, 22^{\circ} 07^{\prime} 43.8^{\prime \prime} \mathrm{E}, 390 \mathrm{~m}$ n.p.m., about 45 shoots in gap in a beech-hornbeam forest (Bober 1974; FMP Brzozów 2017). Przemyśl Foothills:-Ulucz a, 4940'44.7"N, $22^{\circ} 16^{\prime} 13.0^{\prime \prime} \mathrm{E}, 280 \mathrm{~m}$ a.s.1., about 50 shoots on the edge of an ash forest. Site of undetermined status near the ruins of a Ukrainian village (Deptuch \& Oklejewicz 1998; FMP Dynów
2016).-Ulucz b, $49^{\circ} 40^{\prime} 51.4^{\prime \prime} \mathrm{N}, 22^{\circ} 15^{\prime} 50.1^{\prime \prime} \mathrm{E}, 270 \mathrm{~m}$ a.s.1., over a dozen shoots in a thinned oak-maple forest with hazel in the understory. Site of undetermined status near the ruins of a Ukrainian village (Deptuch \& Oklejewicz 1998; FMP Dynów 2016).-Ulucz c, $49^{\circ} 40^{\prime} 58.4^{\prime \prime} \mathrm{N}, 22^{\circ} 15^{\prime} 33.0^{\prime \prime} \mathrm{E}, 270 \mathrm{~m}$ a.s.1., five shoots in an oak-ash forest. Site of undetermined status near the ruins of a Ukrainian village (Deptuch \& Oklejewicz 1998; FMP Dynów 2016).-UUlucz d, 4941'02.2"N, $22^{\circ} 15^{\prime} 24.2^{\prime \prime} \mathrm{E}, 265 \mathrm{~m}$ a.s.l., seven shoots in a maple-ash forest with hazel in understory. Site of undetermined status near the ruins of a Ukrainian village. (Deptuch \& Oklejewicz 1998; FMP Dynów 2016).--Ulucz e, 4941'06.4"N $2^{\prime \prime} 2^{\circ} 15^{\prime} 33.8^{\prime \prime} \mathrm{E}, 280 \mathrm{~m}$ a.s.l., over a dozen shoots in a maple-ash forest with hazel in the understory. Site of undetermined status near the ruins of a Ukrainian village (Deptuch \& Oklejewicz 1998; FMP Dynów 2016).-_Ulucz f (!), $49^{\circ} 40^{\prime} 59.3^{\prime \prime} \mathrm{N}, 22^{\circ} 16^{\prime} 40.6^{\prime \prime} \mathrm{E}, 360 \mathrm{~m}$ a.s.1., about 30 shoots in a mixed forest dominated by Scots pine. Site of undetermined status near the ruins of a Ukrainian village (Deptuch \& Oklejewicz 1998; FMP Dynów 2016).-Dylągowa (!), $49^{\circ} 45^{\prime} 07.9^{\prime \prime} \mathrm{N}, 22^{\circ} 19^{\prime} 15.5^{\prime \prime} \mathrm{E}, 465 \mathrm{~m}$ a.s.1., four shoots in a larch forest (FMP Dynów 2016). - Leoncina a, 4947'58.8'N, $22^{\circ} 40^{\prime} 11.4^{\prime \prime} \mathrm{E}, 230 \mathrm{~m}$ a.s.1., 15 shoots in a beech-oak forest (Denisiuk et al. 1993; Malik \& Nogawka 1999; FMP Krasiczyn 2018).-—Leoncina b, 49 $47^{\prime} 52.5^{\prime \prime} \mathrm{N}, 22^{\circ} 39^{\prime} 49.6^{\prime \prime} \mathrm{E}, 260 \mathrm{~m}$ a.s.1., about 40 shoots in a beech-oak forest in a Nature Reserve area (Denisiuk et al. 1993; Malik \& Nogawka 1999; FMP Krasiczyn 2018).-—Leoncina c, $49^{\circ} 47^{\prime} 49.3^{\prime \prime} \mathrm{N}, 22^{\circ} 39^{\prime} 36.5^{\prime \prime} \mathrm{E}, 250 \mathrm{~m}$ a.s.1., 4 shoots in a beech-oak forest (Denisiuk et al. 1993; Malik \& Nogawka 1999; FMP Krasiczyn 2018).-Leoncina d, $49^{\circ} 47^{\prime} 46.8^{\prime \prime} \mathrm{N}, 22^{\circ} 39^{\prime} 29.1^{\prime \prime} \mathrm{E}, 265 \mathrm{~m}$ a.s.1., 10 shoots in a beech-oak forest (FMP Krasiczyn 2018).-Leoncina e, $49^{\circ} 47^{\prime} 26.3^{\prime \prime} \mathrm{N}, 22^{\circ} 39^{\prime} 22.8^{\prime \prime} \mathrm{E}, 260 \mathrm{~m}$ a.s.1., 20 shoots in an oak-hornbeam forest (Denisiuk et al. 1993; Malik \& Nogawka 1999; FMP Krasiczyn 2018).-Prałkowce a, 4946'32.4"N, $22^{\circ} 42^{\prime} 45.7^{\prime \prime} \mathrm{E}, 225 \mathrm{~m}$ a.s.1., many young shoots growing dispersed in a hornbeam forest (Kotula 1881; Batko 1934; Gostyńska 1961; Piórecki 2013; Wolanin 2014; FMP Krasiczyn 2018)._Prałkowce b, $49^{\circ} 46^{\prime} 27.8^{\prime \prime} \mathrm{N}, 22^{\circ} 42^{\prime} 13.1^{\prime \prime} \mathrm{E}, 275 \mathrm{~m}$ a.s.1., many young shoots growing dispersed in a beech forest (Kotula 1881; Batko 1934; Gostyńska 1961; Piórecki 2013; Wolanin 2014; FMP Krasiczyn 2018).-Prałkowce c, $49^{\circ} 46^{\prime} 19.2^{\prime \prime} \mathrm{N}$, $22^{\circ} 42^{\prime} 36.7^{\prime \prime} \mathrm{E}, 300 \mathrm{~m}$ a.s.1., about 130 shoots in an oak-hornbeam forest (Kotula 1881; Batko 1934; Gostyńska 1961; Piórecki 2013; FMP Krasiczyn 2018).-Dybawka Górna, 4945'52.2”N, $22^{\circ} 40^{\prime} 39.2^{\prime \prime} \mathrm{E}, 350 \mathrm{~m}$ a.s.1., about 10 shoots in a beech-larch forest (Piórecki 2013; Wolanin 2014; FMP Krasiczyn 2018).Kruhel Wielki a, $49^{\circ} 45^{\prime} 57.8^{\prime \prime} \mathrm{N}, 22^{\circ} 44^{\prime} 27.9^{\prime \prime} \mathrm{E}, 310 \mathrm{~m}$ a.s.1., about 90 shoots in a beech-hornbeam forest (Kotula 1881; Gostyńska 1961; Piórecki 2013; Wolanin 2014; FMP Krasiczyn

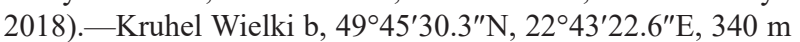
a.s.1., about 10 shoots in a beech-oak forest (Kotula 1881; Gostyńska 1961; Wolanin 2014; FMP Krasiczyn 2018).-Góra Wapielnica, $49^{\circ} 45^{\prime} 19.6^{\prime \prime} \mathrm{N}, 22^{\circ} 43^{\prime} 37.4^{\prime \prime} \mathrm{E}, 370 \mathrm{~m}$ a.s.l., about 500 shoots in a birch-oak forest (Kotula 1881; Gostyńska 1961; Kozłowska 2000; Piórecki 2013; Wolanin 2014; FMP Krasiczyn

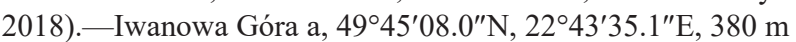
a.s.1., about 30 shoots in a beech-hornbeam forest (Kotula 1881; Gostyńska 1961; Kozłowska 2000; Piórecki 2013; Wolanin 2014; FMP Krasiczyn 2018). - Iwanowa Góra b, 49² $45^{\prime} 03.5^{\prime \prime} \mathrm{N}$, $22^{\circ} 43^{\prime} 38.5^{\prime \prime} \mathrm{E}, 395 \mathrm{~m}$ a.s.1., about 220 shoots in young beech forest and in the ditches within the former fort (Kotula 1881; Gostyńska 1961; Kozłowska 2000; Piórecki 2013; Wolanin 2014; FMP Krasiczyn 2018).--Iwanowa Góra c, 4944'57.4”N, $22^{\circ} 43^{\prime} 50.8^{\prime \prime} \mathrm{E}, 385 \mathrm{~m}$ a.s.1., about 20 shoots in an oak-hornbeam forest with a large proportion of beech (Kotula 1881; Gostyńska 1961; Kozłowska 2000; Piórecki 2013; Wolanin 2014; FMP 
Krasiczyn 2018).-Iwanowa Góra d, 4944'50.6"N, $22^{\circ} 43^{\prime} 29.9^{\prime \prime} \mathrm{E}, 380 \mathrm{~m}$ a.s.l., about 100 shoots in an oak-hornbeam forest with an unnaturally large proportion of beech (Kotula 1881; Gostyńska 1961; Kozłowska 2000; Piórecki 2013; Wolanin 2014; FMP Krasiczyn 2018). - Iwanowa Góra e, $49^{\circ} 45^{\prime} 00.4^{\prime \prime} \mathrm{N}, 22^{\circ} 43^{\prime} 02.4^{\prime \prime} \mathrm{E}, 360 \mathrm{~m}$ a.s.1., about 120 shoots in an oak-hornbeam forest with a large proportion of beech (Kotula 1881; Gostyńska 1961; Kozłowska 2000; Piórecki 2013; Wolanin 2014; FMP Krasiczyn 2018). Góra Wapielnica and Iwanowa Góra previously reported as 'Lipnik' (Kotula 1881).-

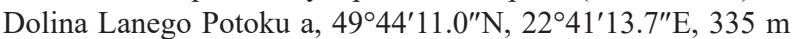
a.s.l., about 35 shoots in a beech-sycamore forest (Wolanin 2014; FMP Krasiczyn 2018).-Dolina Lanego Potoku b, $49^{\circ} 44^{\prime} 02.4^{\prime \prime} \mathrm{N}, 22^{\circ} 41^{\prime} 19.3^{\prime \prime} \mathrm{E}, 370 \mathrm{~m}$ a.s.1., about 45 shoots in a beech-sycamore forest (Wolanin 2014; FMP Krasiczyn

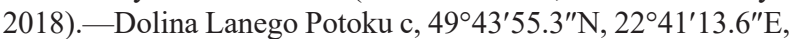
$390 \mathrm{~m}$ a.s.l., about 40 shoots in a beech-larch forest (Wolanin 2014; FMP Krasiczyn 2018).-Olszany a, 4943'54.7"N, $22^{\circ} 36^{\prime} 18.1^{\prime \prime} \mathrm{E}, 330 \mathrm{~m}$ a.s.1., 10 shoots in a beech-fir forest (Kotula 1881; Piórecki 2013; Wolanin 2014; FMP Krasiczyn 2018).Olszany b, 49 $43^{\prime} 42.1^{\prime \prime} \mathrm{N}, 22^{\circ} 36^{\prime} 22.4^{\prime \prime} \mathrm{E}, 370 \mathrm{~m}$ a.s.1., 9 shoots in a beech forest (Piórecki 2013; Wolanin 2014; FMP Krasiczyn 2018).-Olszany c, $49^{\circ} 43^{\prime} 39.1^{\prime \prime} \mathrm{N}, 22^{\circ} 36^{\prime} 15.6^{\prime \prime} \mathrm{E}, 360 \mathrm{~m}$ a.s.1., 4 shoots in a beech forest (Kotula 1881; Piórecki 2013; Wolanin 2014; FMP Krasiczyn 2018).-Brylińce, 4942'43.3"N, $22^{\circ} 37^{\prime} 42.2^{\prime \prime} \mathrm{E}, 330 \mathrm{~m}$ a.s.1., 20 shoots in a beech-hornbeam forest (Batko 1934; Gostyńska 1961; Wolanin 2014; FMP Krasiczyn 2018).--Kopysno, $49^{\circ} 41^{\prime} 32.4^{\prime \prime} \mathrm{N}, 22^{\circ} 37^{\prime} 49.0^{\prime \prime} \mathrm{E}, 430 \mathrm{~m}$ a.s.1., about 55 shoots in a beech-hornbeam forest (FMP Krasiczyn

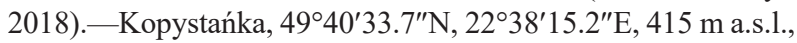
about 50 shoots on the former hillfort ramparts in a beech forest (Piórecki 2013).-Pod Koniuszą, 4942'06.6"N, 22 $41^{\circ} 17.4^{\prime \prime} \mathrm{E}$, $425 \mathrm{~m}$ a.s.1., about 30 shoots in a beech-hornbeam forest (Piórecki 2013; Wolanin 2014; FMP Krasiczyn 2018)—Góra Helicha a, $49^{\circ} 44^{\prime} 25.3^{\prime \prime} \mathrm{N}, 22^{\circ} 42^{\prime} 37.5^{\prime \prime} \mathrm{E}, 425 \mathrm{~m}$ a.s.1., about 80 shoots in a larch forest (Gostyńska 1961; Kozłowska 2000; Wolanin 2014; FMP Krasiczyn 2018).-Góra Helicha b, $49^{\circ} 44^{\prime} 40.9^{\prime \prime} \mathrm{N}, 22^{\circ} 43^{\prime} 01.1^{\prime \prime} \mathrm{E}, 390 \mathrm{~m}$ a.s.1., about 200 shoots in a beech-sycamore forest (Gostyńska 1961; Kozłowska 2000; Piórecki 2013; Wolanin 2014; FMP Krasiczyn 2018).- Rok-

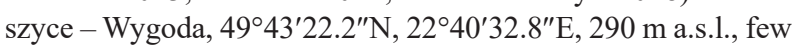
shoots in a fir-sycamore forest near a stream (Kotula 1881; Gostyńska 1961; Piórecki 2013; Wolanin 2014; FMP Krasiczyn

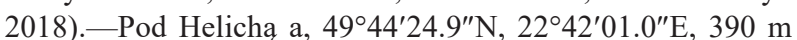
a.s.1., about 65 shoots in a beech-oak forest (Gostyńska 1961; Piórecki 2013; Wolanin 2014; FMP Krasiczyn 2018)._Pod Helichą b, $49^{\circ} 44^{\prime} 14.7^{\prime \prime} \mathrm{N}, 22^{\circ} 42^{\prime} 00.3^{\prime \prime} \mathrm{E}, 400 \mathrm{~m}$ a.s.1., about 90 shoots in an oak-hornbeam forest (Gostyńska 1961; Wolanin

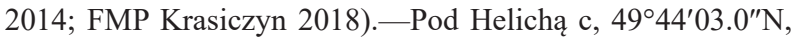
$22^{\circ} 41^{\prime} 48.5^{\prime \prime} \mathrm{E}, 420 \mathrm{~m}$ a.s.1., about 50 shoots in young beech forest (Gostyńska 1961; Piórecki 2013; Wolanin 2014; FMP

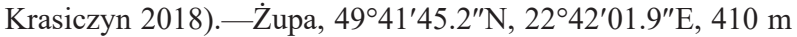
a.s.1., about 50 shoots in an oak-fir forest (FMP Krasiczyn 2018).-Berendowice, $49^{\circ} 40^{\prime} 39.2^{\prime \prime} \mathrm{N}, 22^{\circ} 43^{\prime} 34.1^{\prime \prime} \mathrm{E}, 340 \mathrm{~m}$ a.s.1., about 40 shoots in a beech-fir forest (FMP Krasiczyn 2018).-Kalwaria Pacławska, $49^{\circ} 38^{\prime} 24.8^{\prime \prime} \mathrm{N}, 22^{\circ} 42^{\prime} 23.5^{\prime \prime} \mathrm{E}$, $340 \mathrm{~m}$ a.s.l., about 60 shoots in a beech-sycamore forest in a Nature Reserve area (FMP Bircza 2018).-Kalwaria Pa-

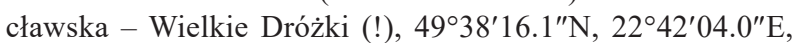
$415 \mathrm{~m}$ a.s.1., 30 shoots in a small, forested ravine among the meadows.-- Rybotycze (!), 49 $39^{\circ} 24.5^{\prime \prime} \mathrm{N}, 22^{\circ} 38^{\prime} 46.4^{\prime \prime} \mathrm{E}, 300 \mathrm{~m}$ a.s.1., three shrubs near an inhabited house (Milczarek P. \& Milczarek I. - unpubl. data).-Makowa, 49³8'06.7"N, $22^{\circ} 40^{\prime} 14.5^{\prime \prime} \mathrm{E}, 390 \mathrm{~m}$ a.s.1., about 35 shoots in a pine-hornbeam forest (Cymbała R. \& Kuńka K. - unpubl. data).-Dolina Sopotnika a (!), $49^{\circ} 37^{\prime} 58.8^{\prime \prime} \mathrm{N}, 22^{\circ} 41^{\prime} 18.9^{\prime \prime} \mathrm{E}, 318 \mathrm{~m}$ a.s.1., 17 shoots on the banks of the ravine in a beech-hornbeam forest (Bobiec A. - unpubl. data, Kucharzyk S. - unpubl. data).-Dolina Sopotnika b (!), 49 $37^{\prime} 56.6^{\prime \prime} \mathrm{N}, 22^{\circ} 41^{\prime} 22.4^{\prime \prime} \mathrm{E}, 320 \mathrm{~m}$ a.s.1., 50 shoots on the banks of the ravine in a beech-hornbeam forest (Bobiec A. - unpubl. data; Kucharzyk S. - unpubl. data).-Dolina Sopotnika c (!), 49 $37^{\prime} 52.9^{\prime \prime} \mathrm{N}, 22^{\circ} 41^{\prime} 31.0^{\prime \prime} \mathrm{E}, 340 \mathrm{~m}$ a.s.1., 6 shoots on the banks of the ravine in a beech-hornbeam forest (Bobiec A. - unpubl. data; Kucharzyk S. - unpubl. data).-Dolina Sopotnika d (!), 49 $37^{\prime} 50.1^{\prime \prime} \mathrm{N}, 22^{\circ} 41^{\prime} 30.3^{\prime \prime} \mathrm{E}, 340 \mathrm{~m}$ a.s.1., one shoot on the ravine bank in a beech-hornbeam forest (Bobiec A. unpubl. data; Kucharzyk S. - unpubl. data).-Dolina Sopotnika e (!), 49 $37^{\prime} 39.8^{\prime \prime} \mathrm{N}, 22^{\circ} 41^{\prime} 30.8^{\prime \prime} \mathrm{E}, 350 \mathrm{~m}$ a.s.l., one shoot on the ravine bank in a beech-hornbeam forest (Bobiec A. - unpubl. data).-Dolina Sopotnika f (!), 49 $37^{\prime} 07.3^{\prime \prime} \mathrm{N}, 22^{\circ} 41^{\prime} 13.2^{\prime \prime} \mathrm{E}$, $340 \mathrm{~m}$ a.s.l., one shoot on the ravine bank in a beech-hornbeam forest (Bobiec A. - unpubl. data).-Dolina Sopotnika g (!), $49^{\circ} 37^{\prime} 18.5^{\prime \prime} \mathrm{N}, 22^{\circ} 41^{\prime} 39.2^{\prime \prime} \mathrm{E}, 365 \mathrm{~m}$ a.s.1., 5 shoots dispersed on the east slope of the Sopotnik Valley in a beech-hornbeam forest (Bobiec A. - unpubl. data).-Pacław - Ubocz a (!), $49^{\circ} 37^{\prime} 14.2^{\prime \prime} \mathrm{N}, 22^{\circ} 43^{\prime} 00.6^{\prime \prime} \mathrm{E}, 400-430 \mathrm{~m}$ a.s.1., about 30 shoots on a west slope of Ubocz Hill in an oak-hornbeam forest (Bobiec A. - unpubl. data).-Pacław - Ubocz b (!), 49³6 $36^{\prime} 52.3^{\prime \prime} \mathrm{N}$, $22^{\circ} 43^{\prime} 19.4^{\prime \prime} \mathrm{E}, 405 \mathrm{~m}$ a.s.l., about 20 shoots on a west slope of Ubocz Hill in an oak-hornbeam forest (Milczarek P. \& Milczarek I. - unpubl. data). Gorlice Basin:-Belna, 4943'43.6"N, $21^{\circ} 16^{\prime} 07.5^{\prime \prime} \mathrm{E}, 280-300 \mathrm{~m}$ a.s.1., about 60 shoots in a few clusters on the steep bank of the Ropa River in an oak-hornbeam forest (Kotowicz 1877; Chrostowski 1962; Gostyńska 1961; Kornaś \& Wróbel 1972; Kornaś et al. 1996; Malik \& Nogawka 1999). Jasło-Krosno Basin:-Besko, 49³4'52.3"N, $21^{\circ} 56^{\prime} 41.7^{\prime \prime} \mathrm{E}, 310 \mathrm{~m}$ a.s.l., over a dozen shoots in an oak-hornbeam forest on the slope of the Wisłok River (Oklejewicz 1993; Przemyski A. - unpubl. data). Jasło Foothills:-Widacz, $49^{\circ} 49^{\prime} 02.2^{\prime \prime} \mathrm{N}, 21^{\circ} 38^{\prime} 02.0^{\prime \prime} \mathrm{E}, 245 \mathrm{~m}$ a.s.1., about 100 shoots on the edge of an oak-hornbeam forest at the base of the slope (Oklejewicz et. al. 2008; Łuczaj Ł. - unpubl. data).-Głojsce, $49^{\circ} 34^{\prime} 32.7^{\prime \prime} \mathrm{N}, 21^{\circ} 38^{\prime} 27.9^{\prime \prime} \mathrm{E}, 480 \mathrm{~m}$ a.s.1., about 40 shoots in a beech forest. Previously reported as 'Lasy między Frankowem a Draganową' (Gostyńska 1961; FMP Dukla 2018).--Makowiska a $\left[49^{\circ} 35^{\prime} 16.4^{\prime \prime} \mathrm{N}, 2^{\circ} 35^{\prime} 05.9^{\prime \prime} \mathrm{E}, 450 \mathrm{~m}\right.$ a.s.l., about 25 shoots in an ash-sycamore forest (Gostyńska 1961; Oklejewicz 1993; FMP Dukla 2018).-Makowiska b, 49³5'16.5”N, $21^{\circ} 35^{\prime} 14.4^{\prime \prime} \mathrm{E}, 440 \mathrm{~m}$ a.s.l., about 40 shoots in a beech forest (Gostyńska 1961; Oklejewicz 1993; FMP Dukla 2018).-Grodzisko Wietrzno, $49^{\circ} 36^{\prime} 44.7^{\prime \prime} \mathrm{N}, 2^{\circ} 42^{\prime} 31.1^{\prime \prime} \mathrm{E}, 420 \mathrm{~m}$ a.s.1., about 10 shoots in a beech-hornbeam forest and on a former hillfort ramparts (Gostyńska 1961, Malik \& Nogawka 1999), previously reported as ' $\mathrm{m}$. Myszkowskim a Bóbrką' (Oklejewicz et al. 2008).-Podniebyle - Skrzypieniec a, 49 $40^{\prime} 52.4^{\prime \prime} \mathrm{N}$, $21^{\circ} 38^{\prime} 29.9^{\prime \prime} \mathrm{E}, 325 \mathrm{~m}$ a.s.1., about 20 shoots in a beech-fir forest (Oklejewicz 1993; FMP Kołaczyce).—Podniebyle - Skrzypieniec b, $49^{\circ} 40^{\prime} 51.7^{\prime \prime} \mathrm{N}, 21^{\circ} 38^{\prime} 18.7^{\prime \prime} \mathrm{E}, 350 \mathrm{~m}$ a.s.1., about 20 shoots in a beech-fir forest (Oklejewicz 1993; FMP Kołaczyce).- Lężyny, $49^{\circ} 38^{\prime} 30.8^{\prime \prime} \mathrm{N}, 21^{\circ} 32^{\prime} 39.5^{\prime \prime} \mathrm{E}, 310-350 \mathrm{~m}$ a.s.l., several dozen shoots in a beech forest. Previously reported as 'Łężyny, Gorzyce and Łubienko' (Oklejewicz et al. 2008). - Brzezówka, $49^{\circ} 43^{\prime} 33.9^{\prime \prime} \mathrm{N}, 21^{\circ} 37^{\prime} 06.1^{\prime \prime} \mathrm{E}, 280 \mathrm{~m}$ a.s.1., about 30 shoots on the former hillfort rampart and steep slopes in a beech forest and in an oak-hornbeam forest (Oklejewicz et al. 2008; Łuczaj Ł. - unpubl. data). Previously reported as 'Jedlicze-Męcinka' (Towpasz 1987). Bukowiec Foothills:-Las Grabiński, $\left.49^{\circ} 35^{\prime} 22.7^{\prime \prime} \mathrm{N}, 21^{\circ} 46^{\prime} 18.5^{\prime \prime} \mathrm{E}\right]$ (!) $385 \mathrm{~m}$ a.s.l., about 10 shoots on a ravine slope in a beech-hornbeam forest (FMP Dukla

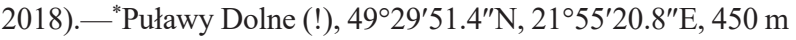
a.s.l., one old shrub of undefined origin and age (Szewczyk M. - unpubl. data).-Wolica a, $49^{\circ} 30^{\prime} 43.0^{\prime \prime} \mathrm{N}, 22^{\circ} 03^{\prime} 36.9^{\prime \prime} \mathrm{E}, 450 \mathrm{~m}$ 
a.s.1., 50 shoots in a larch-beech-oak forest (Oklejewicz 1993,

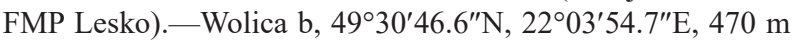
a.s.1., 50 shoots in a fir-oak forest (Oklejewicz 1993; FMP Lesko).- ${ }^{*}$ Trepcza (!), 49 $35^{\prime} 03.6^{\prime \prime} \mathrm{N}, 22^{\circ} 11^{\prime} 03.8^{\prime \prime} \mathrm{E}, 295 \mathrm{~m}$ a.s.1., one old shrub in the fence of the inhabietd farm. Low Beskid Mts:-“'Góra Mużeń (!), 49³7'52.1"N, 2044'22.2"E, 420 m a.s.l., one old shrub of undefined age on a beech-fir forest edge (Michalik A. - unpubl. data).- Piątkowa (!), 49 $37^{\prime} 37.5^{\prime \prime} \mathrm{N}$, $20^{\circ} 46^{\prime} 05.5^{\prime \prime} \mathrm{E}, 418 \mathrm{~m}$ a.s.1., one old shrub, in thickets, near an inhabited house (Michalik A. - unpubl. data).- ${ }^{*}$ Szalowa, $49^{\circ} 39^{\prime} 55.6^{\prime \prime} \mathrm{N}, 21^{\circ} 01^{\prime} 59.5^{\prime \prime} \mathrm{E}, 515 \mathrm{~m}$ a.s.l., two old shrubs on a pile of stones in the middle of the pasture (Malik \& Nogawka 1999). - Gródek a (!), 49³7'41.1"N, $21^{\circ} 00^{\prime} 53.6^{\prime \prime} \mathrm{E}, 385 \mathrm{~m}$ a.s.1., one old shrub on the edge of some thickets growing over the ravine. The origin of the specimen is unknown.- ${ }^{*}$ Gródek b (!), $49^{\circ} 37^{\prime} 54.4^{\prime \prime} \mathrm{N}, 21^{\circ} 00^{\prime} 17.3^{\prime \prime} \mathrm{E}, 365 \mathrm{~m}$ a.s.l., two old shrubs next to an inhabited old house.-Kąclowa a, 49 $35^{\prime} 39.5^{\prime \prime} \mathrm{N}$, $20^{\circ} 58^{\prime} 05.2^{\prime \prime} \mathrm{E}, 365 \mathrm{~m}$ a.s.1., three shrubs growing in an oak-hornbeam forest on a steep slope of the right bank of the Biała Tarnowska River (Piechnik et al. 2020). - Kąclowa b (!), $49^{\circ} 36^{\prime} 05.2^{\prime \prime} \mathrm{N}, 20^{\circ} 58^{\prime} 35.3^{\prime \prime} \mathrm{E}, 425 \mathrm{~m}$ a.s.1., three shrubs of undefined age in the area of an inhabited farm (Święs M. - unpubl. data).- Kąclowa c (!), 49 $35^{\prime} 53.6^{\prime \prime} \mathrm{N}, 20^{\circ} 58^{\prime} 02.1^{\prime \prime} \mathrm{E}, 385 \mathrm{~m}$ a.s.l., one old shrub of undefined age next to an inhabited wooden house (Święs M. - unpubl. data).- - Kąclowa d (!), $49^{\circ} 35^{\prime} 49.3^{\prime \prime} \mathrm{N}, 20^{\circ} 58^{\prime} 00.7^{\prime \prime} \mathrm{E}, 395 \mathrm{~m}$ a.s.1., one old shrub of undefined age next to an inhabited house (Święs M. - unpubl. data).- Kąclowa e (!), 49³5'22.9"N, 2058'25.0"E, $380 \mathrm{~m}$ a.s.l., one old shrub of undefined age next to an inhabited wooden house (Święs M. - unpubl. data). - Kąclowa f (!), $49^{\circ} 35^{\prime} 07.3^{\prime \prime} \mathrm{N}, 20^{\circ} 58^{\prime} 19.0^{\prime \prime} \mathrm{E}, 360 \mathrm{~m}$ a.s.1., one 50-year-old shrub in the area of an inhabited farm (Święs M. - unpubl. data).Kąclowa $g(!), 49^{\circ} 34^{\prime} 55.6^{\prime \prime} \mathrm{N}, 20^{\circ} 59^{\prime} 15.7^{\prime \prime} \mathrm{E}, 430 \mathrm{~m}$ a.s.1., seven young shoots on the ravine slope and in the fir forest edge. Site of undetermined status (Święs M. - unpubl. data).- Kąclowa h (!), 49 $34^{\prime} 58.2^{\prime \prime} \mathrm{N}, 20^{\circ} 59^{\prime} 03.0^{\prime \prime} \mathrm{E}, 405 \mathrm{~m}$ a.s.l., one old shrub of undefined age in the area of an inhabited farm (Święs M. unpubl. data).- Kąclowa i (!), 49³4'39.4"N, 20 58'34.9"E, $375 \mathrm{~m}$ a.s.l., two 80 -year-old shrubs next to an inhabited wooden house (Święs M. - unpubl. data).- K Kąclowa j (!), 49³5'52.3"N, $20^{\circ} 57^{\prime} 06.4^{\prime \prime} \mathrm{E}, 390 \mathrm{~m}$ a.s.1., one 80 -year-old shrub next to an inhabited house (Święs M. - unpubl. data).- K Kąclowa k (!), $49^{\circ} 34^{\prime} 58.6^{\prime \prime} \mathrm{N}, 20^{\circ} 56^{\prime} 28.9^{\prime \prime} \mathrm{E}, 530 \mathrm{~m}$ a.s.1., one 80 -year-old shrub next to an abandoned wooden cottage (Święs M. - unpubl. data).- 'Blechnarka (!), 49 $25^{\prime} 07.2^{\prime \prime} \mathrm{N}, 21^{\circ} 11^{\prime} 54.5^{\prime \prime} \mathrm{E}, 550 \mathrm{~m}$ a.s.l., one old shrub of undefined age near a Greek Catholic church (Wierzbowska I. - unpubl. data).- ${ }^{*}$ Pielgrzymka (!), $49^{\circ} 36^{\prime} 18.7^{\prime \prime} \mathrm{N}, 21^{\circ} 25^{\prime} 55.6^{\prime \prime} \mathrm{E}, 320 \mathrm{~m}$ a.s.l., one multi-shoot cluster of roadside trees next to an old orchard. Origin and age unknown (Perzanowska et al. 2014).-Samoklęski, $49^{\circ} 35^{\prime} 51.8^{\prime \prime} \mathrm{N}, 21^{\circ} 28^{\prime} 49.8^{\prime \prime} \mathrm{E}, 330-350 \mathrm{~m}$ a.s.l., about 50 shoots scattered throughout the forest complex, mainly over streams, in a beech-fir forest (Dubiel et al. 1975; Malik \& Nogawka 1999).--Mały Las, $49^{\circ} 35^{\prime} 18.6^{\prime \prime} \mathrm{N}, 21^{\circ} 30^{\prime} 47.6^{\prime \prime} \mathrm{E}, 300-390 \mathrm{~m}$ a.s.1., about 1,000 shoots in an oak-hornbeam and beech forest in the Magurski National Park area (Gostyńska 1961; Malik \& Nogawka 1999; Perzanowska et al. 2014) (Fig. 3D).-Kąty Podpagórek - Srebrny Las, $49^{\circ} 34^{\prime} 31.5^{\prime \prime} \mathrm{N}, 21^{\circ} 30^{\prime} 52.0^{\prime \prime} \mathrm{E}, 330 \mathrm{~m}$ a.s.l., over a dozen shoots in an alder-sycamore forest on the bank of a stream (Malik \& Nogawka 1999).- ${ }^{*}$ Nieznajowa (!), $49^{\circ} 29^{\prime} 26.3^{\prime \prime} \mathrm{N}, 21^{\circ} 23^{\prime} 28.0^{\prime \prime} \mathrm{E}, 440 \mathrm{~m}$ a.s.1., one old shrub near the well and next to the ruins of a house in the former Lemko village Nieznajowa (Nowicki Ł. - unpubl. data).- Krempna (!), $49^{\circ} 30^{\prime} 28.2^{\prime \prime} \mathrm{N}, 21^{\circ} 29^{\prime} 48.3^{\prime \prime} \mathrm{E}, 365 \mathrm{~m}$ a.s.l., one old shrub near the old wooden house (Nowicki Ł. - unpubl. data).- - Huta Polańska (!), $49^{\circ} 26^{\prime} 23.0^{\prime \prime} \mathrm{N}, 21^{\circ} 32^{\prime} 55.8^{\prime \prime} \mathrm{E}, 540 \mathrm{~m}$ a.s.l., about
90 shrubs in the Hucianka Stream valley. Near the ruins of a house in the former Lemko village Huta Polańska in the Magurski National Park area (Perzanowska et al. 2014). - Mały Dział, 49 $34^{\prime} 52.1^{\prime \prime} \mathrm{N}, 21^{\circ} 32^{\prime} 01.0^{\prime \prime} \mathrm{E}, 440-450 \mathrm{~m}$ a.s.l., several hundred shoots on slopes of steep ravines in a sycamore-beech forest (Bodziarczyk \& Zator 2001).-Wielki Dział a, $49^{\circ} 34^{\prime} 37.0^{\prime \prime} \mathrm{N}, 21^{\circ} 32^{\prime} 55.0^{\prime \prime} \mathrm{E}, 430 \mathrm{~m}$ a.s.1., about 40 shoots in an elm-lime forest. On the slopes of ravines and on a forest gap (Święs 1983; Deptuch \& Oklejewicz 1998; Bodziarczyk \& Zator 2001). - Wielki Dział b, 49 $34^{\prime} 31.2^{\prime \prime} \mathrm{N}, 21^{\circ} 32^{\prime} 47.8^{\prime \prime} \mathrm{E}, 470 \mathrm{~m}$ a.s.l., about 100 shoots in a beech-sycamore forest (Deptuch \& Oklejewicz 1998, FMP Dukla 2018).-Wielki Dział c, $49^{\circ} 34^{\prime} 31.1^{\prime \prime} \mathrm{N}, 21^{\circ} 32^{\prime} 34.8^{\prime \prime} \mathrm{E}, 470 \mathrm{~m}$ a.s.1., 20 shoots near the former hillfort in a beech-sycamore forest (FMP Dukla 2018).Wielki Dział d, 49³4'20.8'N ${ }^{\circ} 1^{\circ} 32^{\prime} 35.4^{\prime \prime} \mathrm{E}, 515 \mathrm{~m}$ a.s.l., over a dozen shoots in a sycamore forest (FMP Dukla 2018).-Wielki Dział e, $49^{\circ} 34^{\prime} 12.3^{\prime \prime} \mathrm{N}, 21^{\circ} 32^{\prime} 38.5^{\prime \prime} \mathrm{E}, 545 \mathrm{~m}$ a.s.l., over a hundred shoots in a beech-sycamore forest (FMP Dukla 2018).Wielki Dział f, $49^{\circ} 34^{\prime} 10.3^{\prime \prime} \mathrm{N}, 21^{\circ} 32^{\prime} 40.2^{\prime \prime} \mathrm{E}, 550 \mathrm{~m}$ a.s.1., about 30 shoots in a sycamore forest (FMP Dukla 2018).-Wielki Dział g, 493 $34^{\prime} 08.2^{\prime \prime} \mathrm{N}, 21^{\circ} 32^{\prime} 57.8^{\prime \prime} \mathrm{E}, 535 \mathrm{~m}$ a.s.1., about 100 shoots in a beech-fir forest (FMP Dukla 2018). All sites from Wielki Dział were previously reported as 'Łysa Góra' or 'Grzywacka Góra' (Święs 1983; Deptuch \& Oklejewicz

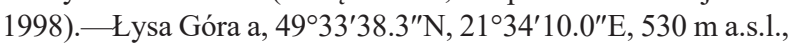
about 120 shoots on the slopes of steep ravines in a sycamore-beech forest (Gostyńska 1961; Święs 1983; Deptuch \& Oklejewicz 1998; Bodziarczyk \& Zator 2001). - Lysa Góra b, $49^{\circ} 33^{\prime} 36.0^{\prime \prime} \mathrm{N}, 21^{\circ} 34^{\prime} 26.0^{\prime \prime} \mathrm{E}, 550 \mathrm{~m}$ a.s.l., few shoots in a former quarry 'Skała' and on a the slopes of a ravine in a sycamore-beech forest (Gostyńska 1961; Święs 1983; Deptuch \& Oklejewicz 1998; Bodziarczyk \& Zator 2001).- - Lysa Góra c, $49^{\circ} 33^{\prime} 58.3^{\prime \prime} \mathrm{N}, 21^{\circ} 34^{\prime} 06.1^{\prime \prime} \mathrm{E}, 480 \mathrm{~m}$ a.s.1., about 100 shoots in a few clusters on the slopes of a ravine in a sycamore-beech forest with larch admixture (Gostyńska 1961; Święs 1983; Deptuch \& Oklejewicz 1998; FMP Dukla 2018). - Łysa Góra d, $49^{\circ} 33^{\prime} 43.0^{\prime \prime} \mathrm{N}, 21^{\circ} 34^{\prime} 04.5^{\prime \prime} \mathrm{E}, 540 \mathrm{~m}$ a.s.l., about 80 shoots on the slopes of a ravine in a sycamore forest (Gostyńska 1961; Święs 1983; Deptuch \& Oklejewicz 1998; FMP Dukla 2018).-

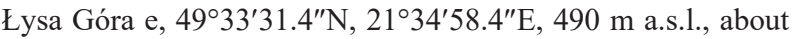
100 shoots in a few clusters on the slopes of a ravine in a fir-sycamore forest (Gostyńska 1961; Święs 1983; Deptuch \& Oklejewicz 1998; FMP Dukla 2018).—— Łysa Góra - Buki (!), $49^{\circ} 35^{\prime} 18.0^{\prime \prime} \mathrm{N}, 2^{\circ} 34^{\prime} 15.4^{\prime \prime} \mathrm{E}, 350 \mathrm{~m}$ a.s.l., one old shrub of undefined age next to an inhabited house.- ${ }^{*}$ Iwla, $49^{\circ} 33^{\prime} 02.9^{\prime \prime} \mathrm{N}$, $21^{\circ} 37^{\prime} 29.2^{\prime \prime} \mathrm{E}, 425 \mathrm{~m}$ a.s.l., one old shrub of undefined age next to the inhabited house no. 68 (Malik \& Nogawka 1999).-Zakluczyn, $49^{\circ} 32^{\prime} 33.8^{\prime \prime} \mathrm{N}, 21^{\circ} 41^{\prime} 51.6^{\prime \prime} \mathrm{E}, 360 \mathrm{~m}$ a.s.1., a few shoots in an oak-hornbeam forest (Tacik et al. 1957; Gostyńska 1961; Malik \& Nogawka 1999). - Cergowa Góra a, 49³2'16.0”N, $21^{\circ} 42^{\prime} 08.9^{\prime \prime} \mathrm{E}, 400-415 \mathrm{~m}$ a.s.1., about 250 shoots dispersed in a beech-fir-sycamore forest (Tacik et al. 1957; Gostyńska 1961; Malik \& Nogawka 1999). - Cergowa Góra b, 49³2'04.7"N, $21^{\circ} 41^{\prime} 55.2^{\prime \prime} \mathrm{E}, 420 \mathrm{~m}$ a.s.l., about 200 shoots in a beech-fir forest in a Nature Reserve area (FMP Dukla 2018).-Lipowica, $49^{\circ} 31^{\prime} 38.3^{\prime \prime} \mathrm{N}, 21^{\circ} 41^{\prime} 16.2^{\prime \prime} \mathrm{E}, 345 \mathrm{~m}$ a.s.1., about 250 shoots in a beech-hornbeam forest (Gostyńska 1961; Malik \& Nogawka 1999).--Nowa Wieś, $49^{\circ} 31^{\prime} 20.5^{\prime \prime} \mathrm{N}, 21^{\circ} 41^{\prime} 14.4^{\prime \prime} \mathrm{E}, 360 \mathrm{~m}$ a.s.1., about 80 shoots on a beech-hornbeam forest edge and on a steep slope (Święs 1982; Szewczyk M. - unpubl. data) (Fig. 3C).Folusz a, 49 $31^{\prime} 14.2^{\prime \prime} \mathrm{N}, 21^{\circ} 39^{\prime} 40.6^{\prime \prime} \mathrm{E}, 475 \mathrm{~m}$ a.s.1., about 40 shoots in a beech forest (Gostyńska 1961; Malik \& Nogawka 1999; FMP Dukla 2018).-Folusz b, 49³1'27.7"N, $21^{\circ} 40^{\prime} 28.7^{\prime \prime} \mathrm{E}, 400 \mathrm{~m}$ a.s.1., about 20 shoots in a beech-fir forest next to a quarry (FMP Dukla 2018).- Wołtuszowa (!), $49^{\circ} 32^{\prime} 06.5^{\prime \prime} \mathrm{N}, 21^{\circ} 51^{\prime} 47.2^{\prime \prime} \mathrm{E}, 440 \mathrm{~m}$ a.s.1., about 10 shoots in 
the area of the former Lemko villlage Woltuszowa (FMP Rymanów 2019; Potasiewicz K. - unpubl. data).-Karlików, $49^{\circ} 26^{\prime} 14.1^{\prime \prime} \mathrm{N}, 22^{\circ} 03^{\prime} 08.4^{\prime \prime} \mathrm{E}, 535 \mathrm{~m}$ a.s.l., a few shoots in a lime-sycamore forest, probably previously reported as 'Tokarnia' (Grodzińska 1968; FMP Lesko 2018).

EASTERN SUBCARPATHIANS. Hermanowice Submontane Region:-Las Hermanowicki (!), 49 42'46.7"N, $22^{\circ} 48^{\prime} 31.8^{\prime \prime} \mathrm{E}, 265 \mathrm{~m}$ a.s.1., a few shoots in an oak-hornbeam forest (FMP Krasiczyn 2018).

OUTER EASTERN CARPATHIANS. Sanocko-Turczańskie Mts.:- Nowosiółki, 49²4'17.4"N ${ }^{\circ} 2^{\circ} 17^{\prime} 24.3^{\prime \prime} \mathrm{E}, 365 \mathrm{~m}$ a.s.l., one old shrub next to a Greek Catholic chapel (Kucharzyk S. - unpubl. data). Bieszczady Mts.:- ${ }^{*}$ Balnica, $49^{\circ} 11^{\prime} 18.3^{\prime \prime} \mathrm{N}$, $22^{\circ} 11^{\prime} 43.0^{\prime \prime} \mathrm{E}, 420 \mathrm{~m}$ a.s.1., one old shrub next to the serfdom cross from 1848 in the former Lemko village Balnica (Szewczyk 2016; Krzyżański M. - unpubl. data).

EASTERN BALTIC LAKE DISTRICT. Ełk Lakeland:-

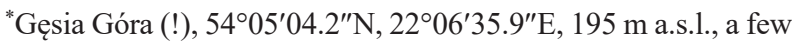
shoots on the slopes of the hillfort that have been damaged by gravel extraction (Sulej A. - unpubl. data).

Despite precise searches, we were unable to find the 45 previously described, probably natural, sites and 8 of the anthropogenic or undetermined origin. They are presented below.

Wapniki (Fiek 1881; Schube 1904; Gostyńska 1961; Boratyński \& Kwiatkowski 1998). Lipa (Boratyński \& Kwiatkowski 1998). Wysoka (Boratyński \& Kwiatkowski 1998). Lubomierz (bei der 'Blauen Pfütze') (Schube 1902; Schube 1904). Lwówek Śląski (Hohlstein) (Schube 1902; Limpricht 1944). Obłoga (Valerienhöhe) (Schube 1902; Limpricht 1944). Muchowskie Wzgórza (Mochenberg) (Schube 1902; Limpricht 1944). "Wilkanów (Boratyński \& Kwiatkowski 1998). "Niemcza (Tatarenschanze) (Browicz \& Gostyńska 1963). *Prudnik - Klasztorne Wzgórze (Kuczyńska 1974). Lichynia (Gostyńska 1961). Otmice (Gilowski \& Jeśman 1975). *Rybnik - Kamień (Urbisz \& Urbisz 2014). *Rybnik - Kuźnia Ligocka (Urbisz \& Urbisz 2014). *Kocierz (Myczkowski 1976; Kotońska 1991). Rachowiec (Kołodziejek 2000). *Gorenice (Oklejewicz et al. 2008). Łęki Dolne (Kornaś \& Wróbel 1972; Kornaś et al. 1996). Kopaliny (Kornaś et al. 1996). Liwocz (Gostyńska 1961). Zboiska (Święs 1982). Kramarzówka (Oklejewicz et al. 2008). Sietesz (Oklejewicz et al. 2008). Wólka Hyżneńska (Oklejewicz et al. 2008). Borek Stary (Oklejewicz et al. 2008). Wola Rafałowska (Oklejewicz et al. 2008). Wielki Las (FMP Strzyżów 2013). Magierów (Oklejewicz et al. 2008). Mójka (Oklejewicz et al. 2008). Paportno (Gostyńska 1961). Równe Kopalnia (Oklejewicz et al. 2008). Sporne (Gostyńska 1961). *Wola Sękowa (Oklejewicz et al. 2008). Kombornia (Gostyńska 1961). Malawa (Gostyńska 1961). Kamionka (Gostyńska 1961). Las Bindulina (Batko 1934; Gostyńska 1961). Krzywcza (Piórecki 2001). Reczpol (Piórecki 2001). Chwaniów Stary (Piórecki 2013). Liskowate (Piórecki 2013). Koniusza (Piórecki 2013). Ropienka (Piórecki 2013). Stańkowa (Piórecki 2013). Kruhel Mały - Wąwóz Maziarnia (Dubiel \& Piórecki 2011; Piórecki 2013). Optyń (Piórecki 2013). Dolina Niemiecka (Piórecki 2013). Suchy Obycz (Michalik 1993). Hyrowa (Święs 1983). Teodorówka (Święs 1983). Tokarnia (Grodzińska 1968). Wielki Dział na Roztoczu (Brzyski 1958).

\section{Discussion}

In Poland, bladdernut is primarily associated with sub-mountain ranges and rarely occurs on sites above $520 \mathrm{~m}$ a.s.1. Most of its sites are at the altitude range of 300-400 m a.s.l. Until recently, the highest natural site
( $640 \mathrm{~m}$ a.s.1.) was described from the Tokarnia in the eastern part of the Low Beskid Mts (Grodzińska 1968). Currently the highest natural bladdernut site $(\sim 550 \mathrm{~m}$ a.s.1.) is the Wielki Dział in the central part of the Low Beskid Mts. However, the sites of anthropogenic origin, where the shrubs flower and fruit, are even higher in Poland, e.g., Skawica Patoroczna in Żywiec-Orawa Beskid Mts (805 m a.s.1.), or Makowica in Sącz Beskid Mts (835 $\mathrm{m}$ a.s.1.). A thorough analysis of the habitat requirements of the species was not conducted during field surveys within the scope of this study. However, it has been confirmed that this shrub requires fertile, calcareous soils, often growing near watercourses, on the steep slopes of ravines (Gostyńska 1961; Niinemets \& Valladares 2006). The most frequent bladdernut populations were found in beech dominated forests (40\% of natural sites) and in oak dominated forests ( $26 \%$ of natural sites). The species was found much less frequently in riparian forests, fir forests, sycamore forests, rocky thickets, and sites with a distorted species composition (pine, larch, or birch forests).

The distribution of the bladdernut has been an object of interest for Polish botanists since the first half of the $18^{\text {th }}$ century. The first documented site of the species in Poland (Dębowa Góra near Krosno) was published in 1721 by Rzączyński (Rzączyński 1721). In subsequent years, descriptions of new sites appeared gradually. It is worth mentioning that both natural and sites of anthropogenic origin were described. By 1956, 68 sites were known in the area of present-day Poland. In his summary publication, Gostyńska reported on 84 sites, including as many as 67 new ones (Gostyńska 1961). Despite this detailed publication, there has been a lot of information about newly discovered sites in later years. 58 new sites were found between 1961 and 1999 (Browicz \& Gostyńska 1963; Grodzińska 1968; Pacyna 1969; Kornaś \& Wróbel 1972; Towpasz 1987; Oklejewicz 1993; Hereźniak et al. 1996; Boratyński \& Kwiatkowski 1998). This was probably connected with more accurate research methods and a thorough analysis of floristic relationships in individual regions based on the ATPOL cartogram method (Zając 1978). The study by Malik \& Nogawka (1999) summarized the existing knowledge on the distribution of the species, and the authors provided 10 new sites in their publication. 193 sites of the bladdernut were already known in Poland in 1999. The last 20 years have been characterized by large-scale inventories of protected areas and managed forests, which resulted in subsequent publications on new occurrences of the species in Poland (Kołodziejek 2000; Gutkowska et al. 2002; Pacyna 2004; Chełmecki 2006; Piątek 2007). During this period, most of new sites of the species were presented in the paper by Oklejewicz et al. (2008). The authors listed as many as 39 previously unpublished sites from the Western Carpathians in Poland. In addition, several kinds of inventory studies such as forest management plans, nature protection programs, databases of national parks and forest inspectorates, as well as graduate student theses in recent years have provided knowledge on the sites of the species. New sites were 
found in subsequent years (Malik 2012; Towpasz \& Stachurska-Swakoń 2015; Piechnik et al. 2020). However, there was a clear tendency to publish reports on natural sites, mainly within the Western Carpathians, with a simultaneous lack of publications from the Sudety Mts \& Sudety Foreland and from the Kraków-Częstochowa Upland. Furthermore, there has been little knowledge so far on the distribution of sites of anthropogenic origin of the bladdernut in Poland.

This paper presents 164 new sites of bladdernut, 48 natural and 116 considered as anthropogenic origin. Before this research, there were about 242 sites of bladdernut published from the area of Poland. It has been confirmed that the areas of Przemyśl Foothills (54 sites) and Dynów Foothills (49 sites) are the most abundant in bladdernut natural sites. The distribution limit of the species based on natural sites changed only slightly in the case of sites from Sudety Mts \& Sudety Foreland, Kraków-Częstochowa Upland, and a significant part of area of the Western Carpathians. The greatest changes in the known distribution were found in the Sudety Mts \& Sudety Foreland, Rożnów Foothills, and the Tarnogród Plateau. One site, (Las Cieszanowicki) recognized as natural, was found in the Strzegom Hills and five new sites (Nowe Rochowice, Podgórki, Komarno, Wojczieszów and Dziwiszów) were found in the Kaczawskie Mts. which significantly changes the view on the natural range of the species in these regions. On the other hand, in the Rożnów Foothills, the only two natural sites (Ostrysz and Pławna) were known from its northern part (Piechnik et al. 2020). The new finding from the south-western edge of Rożnów Foothills (Las Kurowski), presented in this paper, fills the gap between the aforementioned sites, the ones from Białowodzka Góra in Wyspowy Beskid Mts and the closest sites from Low Beskid Mts. One natural site was found in the Tarnogród Plateau (Łukawiec). It is situated halfway between the Przemyśl Foothills, which are rich in natural sites, and Eastern Roztocze, where all of the discovered bladdernut sites have so far been considered as anthropogenic. In the context of published new sites of the species, the Sudety Mts \& Sudety Foreland, Rożnów Foothills and Tarnogród Plateau seem to be areas where we should expect further localizations.

This publication shows that sites of anthropogenic origin show much greater changes in the species' distribution than natural sites. Due to their multiple uses and ornamental value (Heiss et al. 2014), the bladdernut have many sites of anthropogenic origin - backyard and, consequently, often feral (Boratyński \& Kwiatkowski 1998; Malik \& Nogawka 1999). Apart from considerably extending the range of sites of anthropogenic origin, e.g., in Sudety Mts \& Sudety Foreland, Silesia-Kraków Upland, Western Carpathians and Eastern Roztocze, some sites from the area of the Wełtyń Plain, Silesia Lowland, Western Roztocze and Ełk Lakeland are unexpected. The origin of the foregoing sites from areas north of the continuous range area of the species is unknown, but contemporary plantings were ruled out in these cases. In determining affinities with populations from the south of
Poland (natural and anthropogenic) and, consequently, the origin of these sites, can help molecular methods. Some of the sites of anthropogenic origin introduced contemporarily (last 30 years) to the forests were also located during the surveys. Anthropogenic plantings of unknown or non-local origin that were located in areas with a large number of old sites of anthropogenic origin also recorded (Authors' unpublished data). This demonstrates the high popularity of the species, which continues to be artificially introduced into natural habitats. However, it should be noted that such activities require approval of the relevant conservation authorities (Regulation of the Minister of the Environment 2014). The uncontrolled introduction of protected species may pose a threat of diluting the gene pool of their natural sites. Small or remnant plant populations are at particular risk (Potts et al. 2003; Kempf et al. 2018).

\section{Acknowledgements}

We are grateful to all of the persons who helped find bladdernut sites, as well as everyone who provided us with their unpublished data: Błażej Adamczyk, Tomasz Beczała, Waldemar Bena, Bogusław Binkiewicz, Tomasz Biwo, Andrzej Bobiec, Jan Bodziarczyk, Wioletta Bogusz, Maciej Bonk, Joanna Kajzer-Bonk, Adam Boratyński, Magdalena Budzyn, Joanna Bulandra, Stanisław Bulandra, Agnieszka Burghardt, Piotr Chachuła, Krzysztof Ciemny, Robert Cymbała, Bartosz Czader, Ilona Duda, Andrzej Dziadowiec, Małgorzata Dzierwa, Jakub Fitowicz, Dawid Frankowski, Agata Stadnicka-Futoma, Stanisław Garlicki, Stefan Gawroński, Zbigniew Gilarski, Krystyna Grodzińska, Piotr Harazin, Stanislaw Hoczek, Tomasz Jaworski, Tomasz Jonderko, Roman Jurek, Krzysztof Kalemba, Krzysztof Kapała, Piotr Kapusta, Paweł Kauzal, Marek Kaziak, Bartłomiej Kędziora, Piotr Klub, Edyta Knopek, Zofia Kolorz, Krzysztof Konieczny, Anna Medwecka-Kornaś, Marceli Kot, Ryszard Kozik, Tadeusz Krotoski, Marcin Krzeszewski, Marcin Krzyżański, Stanisław Kucharzyk, Mateusz Kulpa, Karolina Olszanowska-Kuńka, Paweł Kwiatkowski, Mateusz Ledwoń, Stefania Loster, Alojzy Lysko, Łukasz Łuczaj, Stanisława Malik, Edward Marszałek, Miłosz Mazur, Wojciech Mazur, Agnieszka Michalik, Łukasz Mielczarek, Ilona Milczarek, Paweł Milczarek, Tomasz Mularczyk, Czesław Narkiewicz, Arkadiusz Nowak, Kamil Nowak, Kazimierz Andrzej Nowak, Łukasz Nowicki, Ewa Ochał, Anna Ociepa, Tomasz Olbrycht, Agnieszka Olszowska, Anna Pędziwiatr, Krzysztof Piątek, Marcin Piątek, Grzegorz Plewniok, Paweł Pluciński, Karolina Potasiewicz, Alojzy Przemyski, Jerzy Rebeś, Grzegorz Rogowski, Jakub Rutana, Monika Rutkowska, Piotr Seget, Bartosz Skowron, Jarosław Sochacki, Justyna Solecka, Dariusz Somerfeld, Jerzy Staszkiewicz, Donata Suder, Andrzej Sulej, Grzegorz Szafran, Ewa Szczęśniak, Paweł Szeptyński, Marian Szewczyk, Magdalena Szymańska, Marcin Śliwka, Krzysztof Świerkosz, Tomasz Święciak, Mateusz Święs, Krystyna Towpasz, Marcin Trybała, Andrzej Trzeciak, Andrzej Tyc, Jan Urban, Alina Urbisz, Andrzej Urbisz, Anna Wajda, Marcin Widlak, Izabela Wierzbowska, Mariusz Wierzgoń, Łukasz Wilk, Katarzyna Wiśniewska, Mateusz Wolanin, Anna Lerch-Wójcik, Adam Zając, Artur Zator, Elżbieta Zając-Zbrożek, Daria Zdyb, Robert Zelek, Jan Zieliński, Marek Żur and Magdalena Żywiec. We would also like to thank Fiona Milne-Rostkowska, as well as all the people not mentioned, who helped us at various stages of this article. We would like to thank three anonymous reviewers for their valuable comments on the manuscript. 


\section{References}

Bajda, K. 2009. Właściwości gleb wybranych stanowisk kłokoczki południowej Staphylea pinnata w Polsce. Master thesis, Faculty of Forestry, Agricultural University in Kraków [manuscript].

Batko, S. 1934. O florze okolic Przemyśla. Kosmos 59: 351-380.

Bober, J. 1974. Notatki florystyczne z południowej części Pogórza Dynowskiego. Zeszyty Naukowe Uniwersytetu Jagiellońskiego, Prace Botaniczne 2: 175-180.

Bodziarczyk, J. \& Zator, A. 2001. Nowe stanowiska Phyllitis scolopendrium (Polypodiaceae) w Beskidzie Niskim. Fragmenta Floristica et Geobotanica Polonica 8: 135-142.

Boratyński, A. \& Kwiatkowski, P. 1998. Chronione i godne ochrony drzewa i krzewy polskiej części Sudetów, Pogórza i Przedgórza Sudeckiego. 10. Staphylea pinnata L. Arboretum Kórnickie 43: 21-30.

Browicz, K. 1959. O rozmnażaniu się kłokoczki południowej (Staphylea pinnata L.). Rocznik Dendrologiczny 13: 125-130.

Browicz, K. 1986. Chorology of trees and shrubs in south-west Asia and adjacent regions. Vol. 5. PWN, Warszawa, Poznań.

Browicz, K. \& Gostyńska, M. 1963. Staphylea pinnata L. - Kłokoczka południowa. In: Białobok, S. \& Czubiński, S. (eds), Atlas Rozmieszczenia Drzew i Krzewów w Polsce, 2, pp. 11-12. Zakład Dendrologii i Arboretum Kórnickie PAN, Poznań.

Bróż, E. \& Przemyski, A. 2009. The red list of vascular plants in the Małopolska Upland (S Poland). In: Mirek, Z. \& Nikel, A. (eds), Rare, relict and endangered plants and fungi in Poland, pp. 123136. Instytut Botaniki PAN im. W. Szafera, Kraków.

Brzyski, B. 1959. Rozmieszczenie i ochrona stanowisk buka i jodły na Roztoczu. Ochrona Przyrody 26: 368-393.

Burghardt, A. 2012. Staphylea pinnata L. i inne rośliny naczyniowe rezerwatu „Husówka” (woj. podkarpackie). Master Thesis, Department of Plant Taxonomy, Adam Mickiewicz University in Poznań [manuscript].

Celiński, F. 1994. Stosunki fitosocjologiczno-leśne Parku Krajobrazowego „Cysterskie Kompozycje Krajobrazowe Rud Wielkich”. Scripta Rudensia 1: 105-117.

Central Register of Forms of Nature Protection [Centralny Rejestr Form Ochrony Przyrody]. [cited 2021 Mar 11]. Available from: http:// crfop.gdos.gov.pl/CRFOP

Chełmecki, Z. 2006. Stanowiska niektórych roślin chronionych na obszarze miasta i gminy Bochnia. Chrońmy Przyrodę Ojczystą 62: 73-77.

Chrostowski, M. 1962. Kłokoczka południowa w dolinie Ropy. Chrońmy Przyrodę Ojczystą 18: 43.

Cieślak, E. 2014. Phylogeography of Pontic-Pannonian species in Central Europe. Polish Botanical Studies 30: 1-53.

Cwener, A., Michalczuk, W. \& Krawczyk, R. 2016. Czerwona lista roślin naczyniowych województwa lubelskiego. Wydawnictwo Uniwersytetu Marii Curie-Skłodowskiej, Lublin.

Denisiuk, Z., Kalemba, A., Mielnicka, B. \& Pilipowicz, W. 1993. Projekt rozszerzenia sieci parków narodowych i rezerwatów w jednostkach terytorialnych. In: Denisiuk, Z. (ed.), Program rezerwatowej ochrony przyrody i krajobrazu Polskich Karpat na tle aktualnej sieci obszarów chronionych. Studia Naturae 39: 26-60.

Deptuch, K., Deptuch, W. \& Oklejewicz, K. 1998. Notatki florystyczne z Pogórza Dynowskiego i Przedgórza Rzeszowskiego (Karpaty Zachodnie). Fragmenta Floristica et Geobotanica, Series Polonica 5: $27-30$.

Deptuch, W. \& Oklejewicz, K. 1998. Notatki florystyczne z Beskidu Niskiego (Karpaty Zachodnie). Fragmenta Floristica et Geobotanica, Series Polonica 5: 21-26.

Drużkowski, M. \& Dubiel, E. 1994. Zbiorowiska roślinne projektowanego rezerwatu przyrody „Dolina potoku Rudno” na tle wybranych elementów środowiska abiotycznego. Ochrona Przyrody 51: $81-105$.
Dubiel, E. \& Piórecki, J. 2011. Szata roślinna Wąwozu Maziarnia w Kruhelu Małym. In: Dubiel, E., Górnicki, A. Hołub, B., Łanczont, M. \& Piórecki, J. (eds), Przyroda Kruhela Małego w Przemyślu. Arboretum Bolestraszyce 14: 27-53.

Dubiel, E., Loster, S., Zając, E. U. \& Zając A. 1975. Notatki florystyczne z Beskidu Niskiego i Dołów Jasielsko-Sanockich. Fragmenta Floristica et Geobotanica 21: 459-461.

Dubiel, E., Loster, S., Zając, E.U. \& Zając, A. 1979. Flora Płaskowyżu Kolbuszowskiego. Materiały do Atlasu rozmieszczenia roślin naczyniowych w Polsce. Zeszyty Naukowe Uniwersytetu Jagiellońskiego, Prace Botaniczne 7: 1-218.

Duda, J. 1997. Gawędy o tajemnicach śląskich żywych skarbów natury - kłokoczka południowa. Przyroda Górnego Śląska 7: 6.

Eliáš, P., Jr., Díté, D., Kliment, J., Hrivnák, R. \& Feráková, V. 2015. Red List of Ferns and Flowering Plants of Slovakia, 5th ed. Biológia 70: 218-228.

Fabijanowski, J. 1959. Projekt utworzenia dwóch rezerwatów leśnych w powiecie kolbuszowskim. Chrońmy Przyrodę Ojczysta 15: 58-62.

Fiek, E. 1881. Flora von Schlesien. J. U. Kern's Verlag, Breslau.

Filkowa, Z. 1987. Gatunki chronione na terenie Niecki Nidziańskiej. Studia Ośrodka Dokumentacji Fizjograficznej 15: 141-161.

Forest Management Plan of Bircza Forest District. 2018. Biuro Urządzania Lasu i Geodezji Leśnej Oddział w Przemyślu, Przemyśl.

Forest Management Plan of Brzozów Forest District. 2017. Biuro Urządzania Lasu i Geodezji Leśnej Oddział w Przemyślu, Przemyśl.

Forest Management Plan of Dębica Forest District. 2018. Biuro Urządzania Lasu i Geodezji Leśnej Oddział w Przemyślu, Przemyśl.

Forest Management Plan of Dukla Forest District. 2018. Biuro Urządzania Lasu i Geodezji Leśnej Oddział w Przemyślu, Przemyśl.

Forest Management Plan of Dynów Forest District. 2016. Biuro Urządzania Lasu i Geodezji Leśnej Oddział w Przemyślu, Przemyśl.

Forest Management Plan of Jawor Forest District. 2018. Biuro Urządzania Lasu i Geodezji Leśnej Oddział w Brzegu, Brzeg.

Forest Management Plan of Kańczuga Forest District. 2013. Biuro Urządzania Lasu i Geodezji Leśnej Oddział w Przemyślu, Przemyśl.

Forest Management Plan of Kołaczyce Forest District. 2018. Biuro Urządzania Lasu i Geodezji Leśnej Oddział w Przemyślu, Przemyśl.

Forest Management Plan of Krasiczyn Forest District. 2018. Biuro Urządzania Lasu i Geodezji Leśnej Oddział w Przemyślu, Przemyśl.

Forest Management Plan of Lesko Forest District. 2018. Biuro Urządzania Lasu i Geodezji Leśnej Oddział w Przemyślu, Przemyśl.

Forest Management Plan of Lubaczów Forest District. 2018. Biuro Urządzania Lasu i Geodezji Leśnej Oddział w Przemyślu, Przemyśl.

Forest Management Plan of Prudnik Forest District. 2010. Biuro Urządzania Lasu i Geodezji Leśnej Oddział w Brzegu, Brzeg.

Forest Management Plan of Rymanów Forest District 2019. Biuro Urządzania Lasu i Geodezji Leśnej Oddział w Przemyślu, Przemyśl.

Forest Management Plan of Strzyżów Forest District. 2013. Biuro Urządzania Lasu i Geodezji Leśnej Oddział w Przemyślu, Przemyśl.

Forest Management Plan of Złoty Potok Forest District. 2016. Biuro Urządzania Lasu i Geodezji Leśnej Oddział w Brzegu, Brzeg.

Gilowski, J. \& Jeśman, M. 1975. Przewodnik po Województwie Opolskim. Nasza Przyroda. Wydawnictwo Ligi Ochrony Przyrody, Warszawa.

Głowacka, B., Karpierz, J. \& Witkowska-Wawer, L. 1996. Plan ochrony rezerwatu „Husówka” na okres od: 1996-01-01 do 2015-12-31. Biuro Urządzania Lasu i Geodezji Leśnej w Przemyślu, Pracownia Sozologiczna.

Gostyńska, M. 1961. Rozmieszczenie i ekologia kłokoczki południowej (Staphylea pinnata L.) w Polsce. Arboretum Kórnickie 6: 5-71.

Gostyńska, M. 1962. Zwyczaje i obrzędy ludowe w Polsce związane z kłokoczką południowa (Staphylea pinnata L.). Rocznik Dendrologiczny 16: 113-120. 
Gostyńska, M. \& Surmiński, J. 1961. Niektóre własności fizyko-mechaniczne i skład chemiczny drewna kłokoczki południowej (Staphylea pinnata L.). Rocznik Dendrologiczny 15: 155-162.

Grodzińska, K. 1968. Rośliny naczyniowe Pasma Bukowicy (Beskid Niski). Fragmenta Floristica et Geobotanica 14: 3-82.

Grulich, V. 2017. Červený seznam cévnatých rostlin CR. In: Grulich, V. \& Chobot, K. (eds), Červený seznam ohrožených druhů České republiky, Cévnaté rostliny; Pŕriroda, pp. 75-132. Agency of Nature Conservation and Landscape Protection of the Czech Republic, Prague.

Grzegorzek, A. 1853. Flora von Tarnow in Galizien. Österreichisches Botanisches Wochenblatt 17: 129-131.

Gutkowska, B., Krowiak, M., Łuczaj, Ł., Niedźwiecka, J. \& Oklejewicz, K. 2002. Notatki florystyczne z Pogórza Dynowskiego (Karpaty Zachodnie). Fragmenta Floristica et Geobotanica Polonica 9: $43-47$.

Gutkowska, B. \& Niedźwiecka, J. 2016. Rośliny Chronione występujące w Dolinie Sanu na odcinku od Trepczy do Kuńkowic. In: Krupa, J. (ed.), Problemy ochrony środowiska przyrodniczego i kulturowego Pogórza Dynowskiego w rozwoju turystyki, pp. 143-157. Dynów.

Heger, R. 1871. Spis roślin jawnokwiatowych z okolic Tarnowa. Sprawozdania Komisji Fizjograficznej Akademii Umiejętności 5: 7-22.

Heiss, A. G., Filipović, D., Nedelcheva, A., Ruß-Popa, G., Wanninger, K., Schramayr, G., Perego, R. \& Jacomet, St. 2014. A Fistful of Bladdernuts: The Shifting Uses of Staphylea pinnata L. as Documented by Archaeology, History, and Ethnology. Folk Life: Journal of Ethnological Studies 52: 95-136.

Hegi, G. 1965. Staphylea pinnata L. In: Illustrierte Flora von Mitteleuropa. V/I, pp. 258-262. Carl Hanser Verlag, München.

Hereźniak, J. 1983. Nowe stanowiska rzadkich i interesujących gatunków roślin naczyniowych w północnej części Wyżyny Śląsko-Krakowskiej. Fragmenta Floristica et Geobotanica 29: 361-384.

Hereźniak, J. 1993. Stosunki geobotaniczno-leśne północnej części wyżyny Śląsko-Krakowskiej na tle zróżnicowania i przemian środowiska. Monografie Botaniczne 75: 1-368.

Hereźniak, J., Grzyl, A., Kołodziejek, J. \& Sieradzki, J. 1996. Materiały do flory północnej części Wyżyny Śląsko-Krakowskiej - rzadkie i interesujące gatunki roślin naczyniowych na obszarach położonych na zachód i południe od Częstochowy. Fragmenta Floristica et Geobotanica, Series Polonica 3: 41-47.

Hyla, W. 1938. Zabytki i osobliwości powiatu częstochowskiego. Ziemia Częstochowska 2: 112-113.

Jaźwa, M. \& Stadnicka-Futoma, A. 2014. Rzadkie, chronione i zagrożone gatunki roślin naczyniowych Przedgórza Rzeszowskiego. Fragmenta Floristica et Geobotanica Polonica 21: 275-285.

Kaznowski, K. 1922. Przyczynek do flory okolic Zawiercia i Wyżyny Kielecko-Sandomierskiej. Kosmos 47: 101-104.

Kaznowski, K. 1929. Rośliny naczyniowe okolic Zawiercia. Sprawozdania Komisji FizjograficznejPolskiej Akademii Umiejętności 62: 185-207.

Kaźmierczakowa, R., Bloch-Orłowska, J., Celka, Z., Cwener, A., Dajdok, Z., Michalska-Hejduk, D., Pawlikowski, P., Szczęśniak, E. \& Ziarnek, K. 2016. Polska czerwona lista paprotników i roślin kwiatowych. Polish Red List of Pteridophytes and Flowering Plants; Instytut Ochrony Przyrody Polskiej Akademii Nauk, Kraków.

Kącki, Z., Dajdok, Z. \& Szczęśniak, E. 2003. Czerwona lista roślin naczyniowych. In: Kącki, Z. (ed.), Zagrożone gatunki flory naczyniowej Dolnego Śląska, pp. 9-65. Instytut Biologii Roślin Uniwersytetu Wrocławskiego \& PTTP pro Natura, Wrocław.

Kempf, M., Hebda, A., Zięba, A. \& Zwijacz-Kozica, T. 2018. Genetic identification of alien larch taxa: the case of the Tatra National Park. Dendrobiology 80: 112-122.

Klichowska, M. 1956. Materiał roślinny z Opola z X-XII w. Pomorania Antiqua 6: 353-362.
Kołodziejek, J. 2000. Nowe stanowisko kłokoczki południowej Staphylea pinnata na Wyżynie Częstochowskiej. Chrońmy Przyrodę Ojczystą 56: 90-91.

Konca, B. 1991. Drzewa i krzewy Góry Chojnik. Prace Karkonoskiego Towarzystwa Naukowego 53: 66-82.

Kornaś, J. \& Wróbel, J. 1972. Materiały do atlasu rozmieszczenia roślin naczyniowych w Karpatach polskich. 5. Staphylea pinnata L. Rocznik Dendrologiczny 26: 27-31.

Kornaś, J., Medwecka-Kornaś, A. \& Towpasz, K. 1996. Rośliny naczyniowe Pogórza Ciężkowickiego (Karpaty Zachodnie). Zeszyty Naukowe Uniwersytetu Jagiellońskiego, Prace Botaniczne 28: 1-170.

Kotońska, B. 1991. Rośliny Naczyniowe Beskidu Małego. Zeszyty Naukowe Uniwersytetu Jagiellońskiego, Prace Botaniczne 23: 9-199.

Kotowicz, A. 1877. Spis roślin w okolicy Biecza zebranych w r. 1876. Sprawozdania Komisji FizjograficznejAkademii Umiejętności 11: 154.

Kotula, B. 1881. Spis roślin naczyniowych z okolic Przemyśla. Sprawozdania Komisji Fizjograficznej Akademii Umiejętności 15: 1-90.

Kozik, R. \& Nabożny, P. 1999. Nowe stanowisko kłokoczki południowej Staphylea pinnata L. na Pogórzu Ciężkowickim. Wszechświat 10-12: 247-249.

Kozłowska, A. 1931. The genetic elements and the origin of the steppe flora in Poland. Mémories de l'Académie Polonaise des Sciences et des Lettres, Classe des Sciences Mathématiques et Naturelles, Ser. B 4: 1-110.

Kozłowska, A. 2000. The forest communities in the Przemyśl Foothills, south east Poland. Fragmenta Floristica et Geobotanica Polonica 45: 345-372.

Krzaczek, T. \& Krzaczek, W. 1983. Materiały florystyczne z Kotliny Sandomierskiej. Rocznik Przemyski 23/24: 399-409.

Kucharzyk, S. 1991. Zbiorowiska leśne projektowanego parku krajobrazowego na Pogórzu Rożnowsko-Ciężkowickim. Master Thesis, Department of Forest Botany and Nature Conservation, Faculty of Forestry, Academy of Agriculture in Kraków [manuscript].

Kuczyńska, J. 1974. Stosunki geobotaniczne Opolszczyzny. 2. Analiza geograficzna flory. Podział geobotaniczny. Acta Universitatis Wratislaviensis, Prace Botaniczne 18: 1-114.

Kwiatkowski, P. 1996. Interesujące i rzadkie gatunki roślin naczyniowych Gór i Pogórza Kaczawskiego. Acta Universitatis Wratislaviensis, Prace Botaniczne 54: 21-37.

Kwiatkowski, P. \& Budzyn, M. 2001. Szata roślinna projektowanego rezerwatu „Bukowa Góra” w Górach Kaczawskich (Sudety Zachodnie). Annales Silesiae 31: 27-51.

Latałowa, M. 1994. The archeobotanical record of Staphylea pinnata L. from the $3 \mathrm{rd} / 4$ th century A. D. in northern Poland. Vegetation History and Archeobotany 3: 121-125.

Limpricht, W. 1944. Kalkpflanzen des Bober - Katzbachgebirges und seiner Vorlagen. Botanische Jahrbücher für Systematik 73(4): $375-417$.

Łuczaj, Ł. 2009. Bladdernut (Staphylea pinnata L.) in Polish folklore. Rocznik Polskiego Towarzystwa Dendrologicznego 57: 23-28.

Malik, R. 2012. Priorytetowe siedliska przyrodnicze oraz cenne gatunki roślin występujące na terenie Nadleśnictwa Olkusz - perspektywy ich zachowania i możliwości ochrony. Faculty of Forestry, Agricultural University in Kraków [manuscript].

Malik, R. \& Nogawka, M. 1998. Występowanie kłokoczki południowej Staphylea pinnata w okolicach Krakowa. Chrońmy Przyrodę Ojczysta 5: 25-34.

Malik, R. \& Nogawka, M. 1999. Kłokoczka południowa Staphylea pinnata L. w Polsce - rozmieszczenie, ekologia, zmienność, zagrożenia i ochrona. Master Thesis, Faculty of Forestry, Academy of Agriculture in Poznań [manuscript].

Melnyk, V. I., Perehrym, M. M. \& Kahalo, O. O. 2009. Staphylea pinnata L. In: Diduk, Ya. P. (ed.), Chervona knyha Ukrayiny: roslynnyi svit. Globalconsulting, Kyiv. 
Meusel, H., Jäger, E., Rauschert, S. \& Weinert, E. 1978. Vergleichende Chorologie der Zentraleuropäischen Flora, 2. G. Fischer Verlag, Jena.

Michalik, S. 1993. Flora roślin naczyniowych projektowanego Turnickiego Parku Narodowego. In: Michalik, S. (ed.), Turniki Park Narodowy w Polskich Karpatach Wschodnich - dokumnetacja projektowa, pp. 47-59. Pro Natura, Kraków.

Myczkowski, S. 1976. Człowiek - Przyroda - Cywilizacja. Kształtowanie zasobów przyrody oraz ochrona biosfery. PWN, Warszawa.

Niinemets, Ü. \& Valladares, F. 2006. Appendix A. Shade, drought, and waterlogging tolerance for 806 species of woody plants from the temperate Northern Hemisphere. In: Niinemets, Ü. \& Valladares, F. Tolerance to shade, drought, and waterlogging of temperate northern hemisphere trees and shrubs, Ecological Monographs 76: 521-547.

Mleczko, P. \& Padoł, J. 2009. Miejscowy Plan Zagospodarowania Przestrzennego „Las Wolski”. Prognoza Oddziaływania na Środowisko. Biuro Planowania Przestrzennego, Urząd Miasta Krakowa, Kraków.

Nowak, K. A. 2012. Flora naczyniowa Grojca. Monografia geobotaniczna. Nakład własny, Warszawa - Żywiec.

Nowak, A., Nowak, S. \& Spałek, K. 2009. Red list of vascular plants of Opole province. Nature Journal 41: 141-158.

Ochał, E. 2009. Stan populacji kłokoczki południowej Staphylea pinnata L. w rezerwacie „Kamera” (Pogórze Strzyżowskie). Master thesis, Institute of Botany, Jagiellonian University, Kraków [manuscript].

Oklejewicz, K., Niedźwiecka, J. \& Stadnicka, A. 2008. Rozmieszczenie kłokoczki południowej (Staphylea pinnata L.) w Karpatach Polskich. Rocznik Dendrologiczny 56: 75-84.

Oklejewicz, K. 1993. Flora Dołów Jasielsko-Sanockich. Zeszyty Naukowe Uniwersytetu Jagiellońskiego, Prace Botaniczne 26: 1-167.

Oklejewicz, K., Wolanin, M. \& Wolanin, M. N. 2015. Czerwona Ksiega Roślin Województwa Podkarpackiego. Zagrożone Gatunki Roślin. Stowarzyszenie na Rzecz Rozwoju i Promocji Podkarpacia 'Pro Carpathia', Rzeszów.

Olszowska, A. 2019. Siedliskowo - drzewostanowe warunki występowania kłokoczki południowej (Staphylea pinnata L. ) na terenie RDLP Krosno. Master thesis. Faculty of Forestry, Warsaw University of Life Sciences [manuscript].

Opravil, E. 1962. Dřeviny z moravských a slezských archeologických nálezu. Acta Musei Silesiae, Ser. A: 47-52.

Pacyna, A. 1969. Notatki florystyczne z Pogórza Wielickiego. Fragmenta Floristica et Geobotanica 15: 147-151.

Pacyna, A. 2004. Rośliny naczyniowe wschodniej części Pogórza Wielickiego i przylegającej części Beskidów (Karpaty Zachodnie). Botanical Papers 38: 1-367.

Parusel, J. B. \& Urbisz, A. (eds). 2012. Czerwona lista roślin naczyniowych województwa śląskiego. In: Strategia ochrony województwa śląskiego na lata 2011-2030. Raport o stanie przyrody województwa ślaskiego. Raporty i Opinie 6: 105-176.

Pawłowska, S. 1972. Floristic Statistics and the elements of the Polish flora. In: Szafer, W. (ed.), The vegetation of Poland, pp. 138-239. Państwowe Wydawnictwo Naukowe, Warszawa.

Piątek, K. 2007. Chronione i zagrożone rośliny naczyniowe okolic Jodłowej na Pogórzu Ciężkowickim. Chrońmy Przyrodę Ojczysta 63: $65-74$

Piechnik, Ł. \& Kurek, P. 2020. Co wiemy na temat rozmieszczenia kłokoczki południowej Staphylea pinnata w Polsce? Chrońmy Przyrodę Ojczysta 76: 40-49.

Piechnik, Ł., Kauzal, P., Kucharzyk, S., Suder, D. \& Święs, M. 2020. Nowe stanowiska kłokoczki południowej Staphylea pinnata L. (Staphyleaceae) w Karpatach Zachodnich. Przeglad Przyrodniczy 31: 3-19.

Piórecki, J. 2001. Pogórze Przemyskie. Arboretum Bolestraszyce 8: $78-128$.
Piórecki, J. 2013. Rośliny naczyniowe dzikie, zadomowione i uprawowe na Pogórzu Przemyskim. Arboretum i Zakład Fizjografii, Bolestraszyce.

Potts, B. M., Barbour, R. C., Hingston, A. B. \& Vaillancourt, R. E. 2003. Genetic pollution of native eucalypt gene pools - identifying the risks. Australian Journal of Botany 51: 1-25.

Perzanowska, J., Chachuła, P., Cykowska, B., Drozdowicz, A., Klepacki, P., Korzeniak, J., Mitka, J., Stebel, A., Suder, D. \& Węgrzyn, M. 2014. Plan ochrony Magurskiego Parku Narodowego - okres 1.01.2016-31.12.2035. Operat Ochrony Flory. Instytut Ochrony Przyrody Polskiej Akademii Nauk, Kraków [manuscript].

Regulation of the Minister of the Environment 2014. Rozporządzenie Ministra Środowiska z dnia 9 października 2014 r. w sprawie ochrony gatunkowej roślin (Dz. U. 2014 poz. 1409).

Rutkowska, M. 2013. O wybranych walorach przyrodniczych i kulturowych lasów Trzebiesławskich Wzgórz (Garb Tarnogórskich, Wyżyna Śląska). Chrońmy Przyrodę Ojczystą 69: 134-146.

Rybníček, K., Dickson, J. \& Rybníčková, E. 1998. Flora and vegetation at about A.D. 1100 in the vicinity of Brno, Czech Republic. Vegetation History and Archaeobotany 7: 155-165. https://doi. org/10.1007/bf01374004

Rzączyński, G. 1721. Historia naturalis curiosa Regni Poloniae, Magni Ducatus Lituaniae annexarumque provinciarum in tractatus $X X$ divisa. Sandomierz.

Schube, T. 1902. Ergebnisse der Durchforschung der schlesischen Phanerogamen - und Gefässkryptogamenflora im Jahre 1901. Jahres - Bericht der Schlesischen Geselschaft für Vaterländische Cultur 79: 23-37.

Schube, T. 1904. Flora von Schlesien, Preußischen und österreichischen Anteils. Verl. Von W. G. Korn, Breslau.

Solon, J., Borzyszkowski, J., Bidłasik, M., Richling, A., Badora, K., Balon, J., Brzezińska-Wójcik, T., Chabudziński, Ł., Dobrowolski, R., Grzegorczyk, I., Jodłowski, M., Kistowski, M., Kot, R., Krąż, P., Lechnio, J., Macias, A., Majchrowska, A., Malinowska, E., Migoń, P., Myga-Piątek, U., Nita, J., Pepińska, E., Rodzik, J., Strzyż, M., Terpiłowski, S. \& Ziaja, W. 2018. Physico-geographical mesoregions of Poland: Verification and adjustment of boundaries on the basis of contemporary spatial data. Geographia Polonica 91: 143-170.

Staszkiewicz, J. \& Witkowski, Z. 1980. Ziemia Sąecka. Wiedza Powszechna, Warszawa.

Suder, D. 2014. Szata roślinna grodzisk i zamczysk w dolinach Raby, Dunajca i Wisłoki (Karpaty Zachodnie). PhD thesis, Institute of Botany, Jagiellonian University, Kraków [manuscript].

Szewczyk, M. 2016. Rośliny w powiecie sanockim. Chronione, zagrożone, rzadkie, inwazyjne. Powiat Sanocki, Sanok.

Środoń, A. 1992. Kłopoty z kłokoczką. Wiadomości Botaniczne 36: 63-67.

Święs, F. 1982. Geobotaniczna charakterystyka lasów dorzeczy Jasiołki i Wisłoka w Beskidzie Niskim. Biblioteka Przemyska, Towarzystwo Przyjaciół Nauk 70: 70-100.

Święs, F. 1983. Zbiorowiska leśne dorzecza Wisłoki w Beskidzie Niskim. Roczniki Nauk Rolniczych, Ser. D 184: 1-104.

Tacik, T., Zającówna, M. \& Zarzycki, K. 1957. Z zagadnień geobotanicznych Beskidu Niskiego. Acta Societatis Botanicorum Poloniae 26: $17-43$.

Towpasz, K. 1987. Rośliny naczyniowe Pogórza Strzyżowskiego. Zeszyty Naukowe Uniwersytetu Jagiellońskiego, Prace Botaniczne 16: $1-160$.

Towpasz, K. 2011. Nowe stanowisko Staphylea pinnata (Staphyleaceae) w okolicy Woli Lubeckiej na Pogórzu Ciężkowickim (Karpaty Zachodnie). Fragmenta Floristica et Geobotanica Polonica 18: $167-169$.

Towpasz, K. 2019. Vascular plants of Pilzno surroundings (South-Eastern Poland). Annales Universitatis Paedagogicae Cracoviensis Studia Naturae 4: 31-64. https://doi.org/10.24917/25438832.4.2 
Towpasz, K. \& Stachurska-Swakoń, A. 2015. Uzupełnienia do flory roślin naczyniowych Pogórza Ciężkowickiego (Karpaty Zachodnie). Fragmenta Floristica et Geobotanica Polonica 22: 15-21.

Urbisz, An. \& Urbisz, A. 2014. Rośliny naczyniowe Rybnika. (Vascular plants of Rybnik). Centrum Dziedzictwa Przyrody Górnego Śląska, Katowice.

Wilk, Ł. 2004. Notatki florystyczne z Podgórza Rzeszowskiego (Kotlina Sandomierska). Fragmenta Floristica et Geobotanica Polonica 11: 93-103.

Wolanin, M. 2014. Rośliny naczyniowe Pogórza Przemyskiego i zachodniej części Płaskowyżu Chyrowskiego. Zeszyty Naukowe Uniwersytetu Jagiellońskiego, Prace Botaniczne 47: 1-383.

Wójcik, T. 2012. Bogactwo florystyczne lasu „Ratosniówki” na Pogórzu Strzyżowskim. Chrońmy Przyrodę Ojczystą 68: 28-35.
Wóycicki, Z. 1914. Obrazy roślinności Królestwa Polskiego. Zeszyt VII Roślinność okolic Częstochowy i Olsztyna. Warszawa.

Zając, A. 1978. Założenia metodyczne Atlasu rozmieszczenia roślin naczyniowych w Polsce. Wiadomości Botaniczne 22: 145-155.

Zając, A. \& Zając, M. 2009. Elementy geograficzne rodzimej flory Polski. Instytut Botaniki Uniwersytetu Jagiellońskiego, Kraków.

Zarzycki, K. 1959. Rodzina Staphyleaceae, Kłokoczkowate. In: Szafer, W. \& Pawłowski, B. (eds), Flora polska. Rośliny naczyniowe Polski i ziem ościennych, 8. Instytut Botaniki PAN, Warszawa.

Zelek, R. 2019. Charakterystyka geobotaniczna i flora roślin naczyniowych zlewni Kamienicy Nawojowskiej ze szczególnym uwzględnieniem roślin użytecznych gospodarczo. PhD thesis, Institute of Botany, Jagiellonian University, Kraków [manuscript]. 